Consumer Views on Transportation and Energy (Third Edition)

M. Kubik
Technical Report NREL/TP-620-39047 January 2006

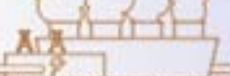




\title{
Consumer Views on Transportation and Energy (Third Edition)
}

\author{
M. Kubik
}

Prepared under Task No. ASA5.1315

\section{Technical Report NREL/TP-620-39047 January 2006}

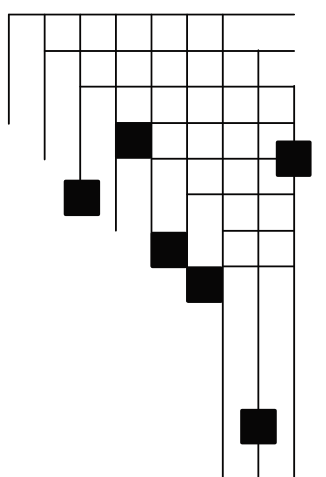

National Renewable Energy Laboratory 1617 Cole Boulevard, Golden, Colorado 80401-3393 303-275-3000 • www.nrel.gov 


\section{NOTICE}

This report was prepared as an account of work sponsored by an agency of the United States government. Neither the United States government nor any agency thereof, nor any of their employees, makes any warranty, express or implied, or assumes any legal liability or responsibility for the accuracy, completeness, or usefulness of any information, apparatus, product, or process disclosed, or represents that its use would not infringe privately owned rights. Reference herein to any specific commercial product, process, or service by trade name, trademark, manufacturer, or otherwise does not necessarily constitute or imply its endorsement, recommendation, or favoring by the United States government or any agency thereof. The views and opinions of authors expressed herein do not necessarily state or reflect those of the United States government or any agency thereof.

Available electronically at http://www.osti.gov/bridge

Available for a processing fee to U.S. Department of Energy and its contractors, in paper, from:

U.S. Department of Energy

Office of Scientific and Technical Information

P.O. Box 62

Oak Ridge, TN 37831-0062

phone: 865.576 .8401

fax: 865.576 .5728

email: mailto:reports@adonis.osti.gov

Available for sale to the public, in paper, from:

U.S. Department of Commerce

National Technical Information Service

5285 Port Royal Road

Springfield, VA 22161

phone: 800.553 .6847

fax: 703.605.6900

email: orders@ntis.fedworld.gov

online ordering: http://www.ntis.gov/ordering.htm 


\section{TABLE OF CONTENTS}

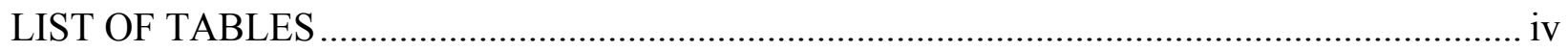

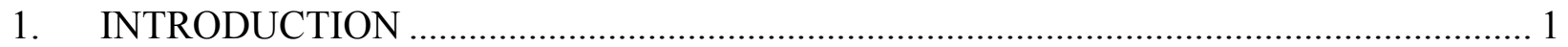

2. ENERGY, OIL, AND POLICY ............................................................................ 2

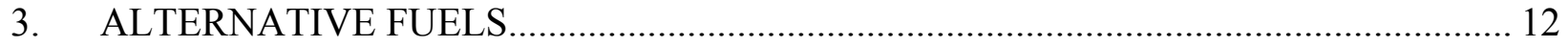

4. CONVENTIONAL, MORE FUEL-EFFICIENT, AND ADVANCED-TECHNOLOGY

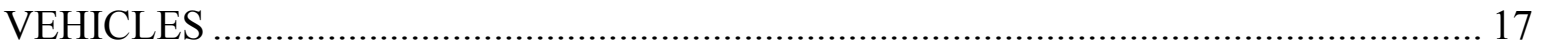

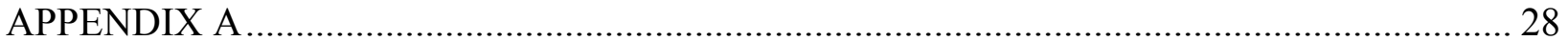




\section{LIST OF TABLES}

Table

Page

2.1.1 Seriousness of Energy Situation (selected years, 1977-2005) .........................................2

2.1.2 Likelihood to Face an Energy Shortage (selected years, 1978-2005) ................................2

2.2.1 Gas Price Increase - Effect on Lifestyle (June 2004) .....................................................

2.2.2 Gas Price Increase - Effect on Finances (selected years, 2000-2005) ..............................3

2.2.3 Gas Price Increase - Response (September 2005) .....................................................4

2.2.4 Fuel Efficiency of New Vehicle (September 2005) ....................................................

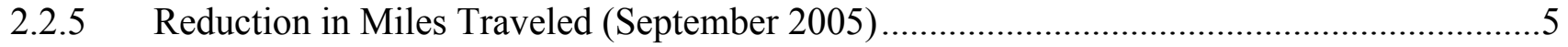

2.2.6 Gas Price Increase - Perceived Cause (May 2004) ...........................................................5

2.2.7 Gas Prices Near \$2.50 a Gallon and Amount Willing to Pay for New Vehicle

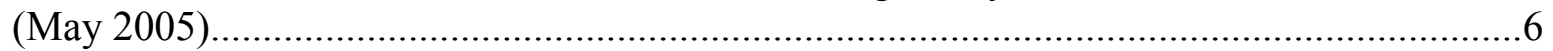

2.2.8 Gas Prices at \$1.50 a Gallon and Amount Willing to Pay for New Vehicle

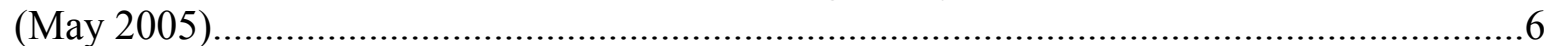

2.2.9 Gas Prices and Willingness to Pay \$2,000 More for New Vehicle (May 2005) ...................7

2.3.1 Energy Production Priorities - Production vs. Conservation (2001-05) .............................8

2.3.2 Energy Production Priorities - Environment vs. Supply (2001-05) .................................8

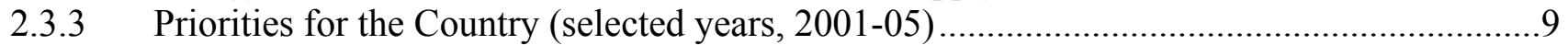

2.3.4 Relaxing Environmental Standards (April 2004) ......................................................10

2.3.5 View of Strictness of Environmental Regulations (May 2005) ........................................10

2.3.6 Quality of the Environment at Various Levels (May 2005) .......................................... 10

2.3.7 Environmental Proposals (March 2003) .................................................................... 11

2.3.8 Ideas for Reducing Dependence on Imported Oil (May 2005).....................................11

3.1.1 Factors Considered "Extremely Important" or "Very Important" in Influencing Decisions to Try a New Fuel Technology (2003) ............................................................................12

3.1.2 Public Perception of Best Fuel and Worst Fuel for Use in Personal Vehicles When Gasoline Is No Longer Available (2000 and 2004) .....................................................12

3.1.3 Reasons Electricity Would Be the Best Fuel for Use in Personal Vehicles When Gasoline Is No Longer Available (2000 and 2004) ........................................................................ 13

3.1.4 Reasons Ethanol Would Be the Best Fuel for Use in Personal Vehicles When Gasoline Is No Longer Available (2000 and 2004) .......................................................................14

3.1.5 Reasons Hydrogen Would Be the Best Fuel for Use in Personal Vehicles When Gasoline Is No Longer Available (2000 and 2004) ................................................................. 14

3.1.6 Reasons Electricity Would Be the Worst Fuel for Use in Personal Vehicles When Gasoline Is No Longer Available (2000 and 2004) .......................................................15

3.1.7 Reasons Ethanol Would Be the Worst Fuel for Use in Personal Vehicles When Gasoline Is No Longer Available (2000 and 2004) .......................................................................15

3.1.8 Reasons Hydrogen Would Be the Worst Fuel for Use in Personal Vehicles When Gasoline Is No Longer Available (2000 and 2004) ................................................................... 16

4.1.1 Trends in Vehicle-Attribute Preference (selected years, 1980-2005)...............................17

4.1.2 Issue Is a Major Reason for Those NOT Considering the Purchase of an SUV (2003)......17

4.2.1 Number of Years Public is Willing to Accept for Payback of Higher Fuel-Economy

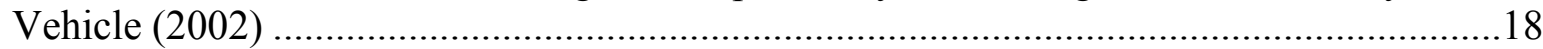

4.2.2 Additional Amount the Public is Willing to Pay for a Vehicle with a 10 Percent Increase

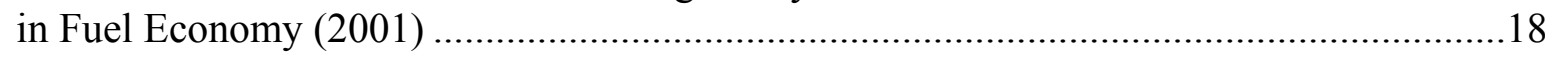


4.2.3 Public Preference Toward Purchasing a More Fuel-Efficient Engine with Different FuelAvailability Options (2000)

4.3.1 Names of Advanced Hybrid-Electric Vehicles Known by the Public (selected years, 2000-04) 20

4.3.2 Public's Attitudes Toward Hybrid-Electric SUVs (2003) ……………...............................2

4.3.3 Level of Consideration for Gas-Electric Hybrid (August 2005) ……..................................21

4.3.4 Importance of Gas Mileage in Next Vehicle (August 2005) ...............................................21

4.3.5 Alternative Fuels to Replace Gasoline and Diesel Fuel in Vehicles (September 2005).......22

4.3.6 Public's Willingness to Pay a Premium for a Clean Diesel Engine (2002)...........................23

4.3.7 Purchase Preference Between Diesel and Gasoline Vehicles by Vehicle Type (2001 and 2005) 23

4.3.8 Reasons for Rejecting a Diesel Option (2001 and 2005) ................................................24

4.3.9 Reasons for Choosing a Diesel Option (2001 and 2005) ................................................25

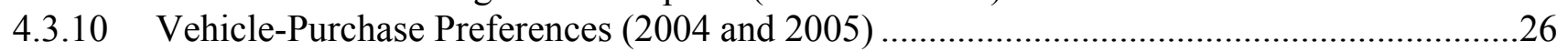

4.3.11 Vehicle-Purchase Preferences - Hybrid-electric vs. Diesel (2004) ....................................26

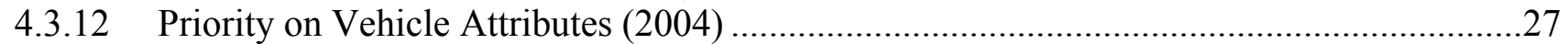

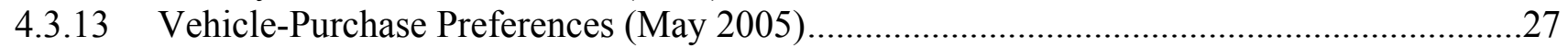




\section{INTRODUCTION}

This report was written to provide the U.S. Department of Energy's (DOE's) Office of Energy Efficiency and Renewable Energy (EERE) with an idea of how the American public views various transportation, energy, and environmental issues.

The data presented in the third edition of this report have been drawn from multiple sources: surveys conducted by the Opinion Research Corporation (ORC) ${ }^{1}$ for the National Renewable Energy Laboratory (NREL) that are commissioned and funded by EERE, Gallup polls, news organization polls, surveys conducted by independent groups and academic institutions, and other sources. Most of the surveys are telephone interviews conducted with randomly selected national samples of adults 18 and older (some were done via the Internet). The surveys use national samples, and the sample size is noted, wherever it is available. The surveys were selected based on their relevance to this overall topic.

The Consumer Views on Transportation and Energy report consists of four sections, including the introduction (Section 1). Section 2 examines public concern about U.S. dependence on imported oil and public assessment of the energy situation in the United States. Section 2 also examines public beliefs about actions to address energy problems, as well as actual and perceived effects of gasoline prices on individuals and households.

Section 3 analyzes what Americans think about alternative fuels such as electricity, ethanol, hydrogen, and other fuel types. Section $\mathbf{4}$ focuses on conventional and advanced-technology vehicles. In this report, advanced-technology vehicles include hybrid-electric and diesel vehicles. Section 4 also analyzes owners' decisions about purchasing more fuel-efficient vehicles and advanced-technology vehicles.

In this edition of Consumer Views on Transportation and Energy, ORC and Gallup poll results for 2002-2005 have been included. ORC surveys were conducted twice a year in 2002, 2004 and 2005 and once in 2003. ${ }^{2}$ The new Gallup polls were conducted throughout 2005. ORC and Gallup asked some of the same energy and environment questions during the past several years. The latest results have been added to the prior ones to show the most current opinions and trends during the past several years.

The report also features new questions from both ORC and Gallup. These 2005 surveys examined "hot" topics such as gas-price increases, environmental issues, and vehicle-purchase preferences.

\footnotetext{
${ }^{1}$ Opinion Research Corporation (ORC) is a research and consulting firm, founded in 1938, that conducts commercial marketing research programs worldwide, in both the private and public sectors.

${ }^{2}$ March 2002, November 2002, March 2003, May and August 2004, May and September 2005.
} 


\section{ENERGY, OIL, AND POLICY}

Public opinion polls reveal that the U.S. public perceives the country's energy situation as a serious issue (Table 2.1.1). This section examines the public's assessment of the energy situation, actual and perceived effects of gasoline prices on driving, and public beliefs about actions to address energy problems.

\subsection{PUBLIC ASSESSMENT OF THE ENERGY SITUATION}

Q2.1.1: How serious would you say the energy situation is in the United States - very serious, fairly serious, or not at all serious?

Table 2.1.1. Seriousness of Energy Situation (selected years, 1977-2005)

\begin{tabular}{|l|c|c|c|c|}
\hline Date & $\begin{array}{c}\text { Very serious } \\
(\mathbf{\%})\end{array}$ & $\begin{array}{c}\text { Fairly } \\
\text { serious (\%) }\end{array}$ & $\begin{array}{c}\text { Not at all } \\
\text { serious (\%) }\end{array}$ & $\begin{array}{c}\text { No opinion } \\
(\mathbf{\%})\end{array}$ \\
\hline March 2005 & 31 & 56 & 10 & 3 \\
\hline March 2004 & 29 & 57 & 12 & 2 \\
\hline March 2003 & 28 & 59 & 11 & 2 \\
\hline March 2002 & 22 & 63 & 12 & 3 \\
\hline March 2001 & 31 & 59 & 9 & 1 \\
\hline Feb. 1991 & 40 & 44 & 14 & 2 \\
\hline Aug. 1990 & 28 & 45 & 23 & 4 \\
\hline April 1979 & 44 & 36 & 16 & 4 \\
\hline March 1978 & 41 & 39 & 15 & 5 \\
\hline April 1977 & 44 & 40 & 11 & 5 \\
\hline
\end{tabular}

Source: Gallup (selected years, 1977-2005), N=496

Q2.1.2: Do you think that the United States is or is not likely to face a critical energy shortage during the next five years?

Table 2.1.2. Likelihood to Face an Energy Shortage (selected years, 1978-2005)

\begin{tabular}{|l|r|r|r|r|}
\hline Date & $\begin{array}{c}\text { Yes, is } \\
(\mathbf{\%})\end{array}$ & $\begin{array}{c}\text { No, is not } \\
(\mathbf{\%})\end{array}$ & $\begin{array}{c}\text { Already } \\
\text { facing one } \\
(\mathbf{\%})\end{array}$ & $\begin{array}{c}\text { No opinion } \\
(\mathbf{\%})\end{array}$ \\
\hline March 2005 & 52 & 45 & $*$ & 3 \\
\hline March 2004 & 49 & 47 & 1 & 3 \\
\hline March 2003 & 56 & 40 & 1 & 3 \\
\hline March 2002 & 48 & 49 & 1 & 2 \\
\hline March 2001 & 60 & 36 & 1 & 3 \\
\hline November 1978 & 45 & 41 & 4 & 10 \\
\hline
\end{tabular}

Source: Gallup (selected years, 1977-2005), N=496 


\subsection{ACTUAL AND PERCEIVED EFFECTS OF GASOLINE PRICES ON DRIVING}

Among those who responded to questions related to this section, it was clear that increases in gas prices affect driving habits and lifestyle traits. This is consistent with data showing that when gasoline prices are lower, people tend to use their vehicles more; and conversely, when gasoline prices increase, driving declines (Table 2.2.1).

Q2.2.1: As a result of the recent rise in gas prices, would you say you have - or have not done each of the following?

Table 2.2.1. Gas Price Increase - Effect on Lifestyle (June 2004)

\begin{tabular}{|l|c|c|c|}
\hline Lifestyle trait & $\begin{array}{c}\text { Yes, have } \\
(\mathbf{\%})\end{array}$ & $\begin{array}{c}\text { No, have not } \\
(\%)\end{array}$ & $\begin{array}{c}\text { No opinion } \\
(\%)\end{array}$ \\
\hline $\begin{array}{l}\text { Made more of an effort to find the gas station } \\
\text { with the cheapest gas in your area }\end{array}$ & 69 & 30 & 1 \\
\hline $\begin{array}{l}\text { Seriously considered getting a more fuel- } \\
\text { efficient car the next time you buy a vehicle }\end{array}$ & 53 & 46 & 1 \\
\hline Cut back significantly on how much you drive & 45 & 54 & 1 \\
\hline $\begin{array}{l}\text { Cut back significantly on your household } \\
\text { spending because of the higher gas prices }\end{array}$ & 34 & 66 & $*$ \\
\hline Altered your summer vacation plans & 29 & 70 & 1 \\
\hline
\end{tabular}

Source: Gallup (June 3-6, 2004), N=465

Q2.2.2: Have recent price increases in gasoline caused any financial hardship for you or your household?

Table 2.2.2. Gas Price Increase - Effect on Finances (selected years, 2000-2005)

\begin{tabular}{|l|c|c|c|}
\hline Timeframe & $\begin{array}{c}\text { Yes, caused } \\
\text { hardship } \\
\mathbf{( \% )}\end{array}$ & $\begin{array}{c}\text { No, has not } \\
\text { caused } \\
\text { hardship } \\
\mathbf{( \% )}\end{array}$ & $\begin{array}{c}\text { No opinion } \\
(\%)\end{array}$ \\
\hline Aug. 28-30, 2005 & 69 & 31 & 0 \\
\hline April 1-2, 2005 & 42 & 58 & 0 \\
\hline May 21-23, 2004 & 47 & 52 & 1 \\
\hline Feb. 17-19, 2003 & 35 & 65 & 0 \\
\hline May 7-9, 2001 & 47 & 53 & 0 \\
\hline May 23-24, 2000 & 36 & 64 & 0 \\
\hline
\end{tabular}

Source: Gallup (selected years, 2000-05), N=465 
Q2.2.3: What has been your or your family's primary response with regard to your vehicle or vehicle travel and the currently high gasoline prices? Anything else? (unaided)

Table 2.2.3. Gas Price Increase - Response (September 2005)

\begin{tabular}{|l|c|c|c|c|c|c|}
\hline Response & $\begin{array}{c}\text { Total } \\
\mathbf{( \% )}\end{array}$ & $\begin{array}{c}\text { Small } \\
\text { car (\%) }\end{array}$ & $\begin{array}{c}\text { Large } \\
\text { car (\%) }\end{array}$ & $\begin{array}{c}\text { Minivan } \\
(\%)\end{array}$ & $\begin{array}{c}\text { Pickup/ } \\
\text { van (\%) }\end{array}$ & $\begin{array}{c}\text { SUV } \\
(\%)\end{array}$ \\
\hline $\begin{array}{l}\text { Drive less (travel less, } \\
\text { consolidate trips, carpool, walk } \\
\text { more, take bus, ride bike more) }\end{array}$ & 44 & 54 & 42 & 53 & 42 & 33 \\
\hline No effect (travel just as often) & 16 & 12 & 24 & 1 & 22 & 21 \\
\hline $\begin{array}{l}\text { Gas prices are ridiculous } \\
\text { (outrageous - too high) }\end{array}$ & 13 & 9 & 13 & 19 & 10 & 12 \\
\hline Don't like it (unhappy, angry) & 8 & 7 & 8 & 10 & 10 & 7 \\
\hline Just pay the price (necessity) & 5 & 3 & 8 & 8 & 6 & 6 \\
\hline Use most efficient vehicle I own & 3 & 2 & 1 & 2 & 2 & 6 \\
\hline Prices are result of gouging & 2 & 3 & 2 & 5 & 4 & 1 \\
\hline Changed vehicle & 2 & 3 & 3 & 1 & 1 & 2 \\
\hline Don't own car/don't drive & 2 & 1 & 1 & 0 & 2 & 1 \\
\hline Other & 9 & 9 & 9 & 8 & 7 & 11 \\
\hline Don't know & 6 & 3 & 3 & 10 & 4 & 7 \\
\hline
\end{tabular}

Source: ORC for NREL (2005b), Study No. 714388, N=1,042

Note: Percentages do not total 100 , because each respondent could volunteer more than one response.

For information on other demographic breakdowns, see Appendix A

Q2.2.4: If these high gasoline prices continued for the next several years, with respect to purchasing a new vehicle, how much more efficient would you want the vehicle you purchase to be? Would you say....... (aided question)

Table 2.2.4. Fuel Efficiency of New Vehicle (September 2005)

\begin{tabular}{|c|c|c|c|c|c|c|}
\hline Efficiency & $\begin{array}{c}\text { Total } \\
\mathbf{( \% )}\end{array}$ & $\begin{array}{c}\text { Small } \\
\text { car }(\mathbf{\%})\end{array}$ & $\begin{array}{c}\text { Large } \\
\text { car (\%) }\end{array}$ & $\begin{array}{c}\text { Minivan } \\
\mathbf{( \% )}\end{array}$ & $\begin{array}{c}\text { Pickup/ } \\
\text { van (\%) }\end{array}$ & $\begin{array}{c}\text { SUV } \\
(\%)\end{array}$ \\
\hline $\mathbf{2 5 \%}$ or less & $\mathbf{2 0}$ & $\mathbf{1 7}$ & $\mathbf{2 9}$ & $\mathbf{1 7}$ & $\mathbf{2 4}$ & $\mathbf{2 8}$ \\
\hline 0 to 15\% more efficient & 9 & 7 & 12 & 11 & 12 & 14 \\
\hline 16 to 25\% more efficient & 11 & 10 & 17 & 7 & 12 & 15 \\
\hline $\mathbf{2 6 \%}$ or more & $\mathbf{6 6}$ & $\mathbf{8 1}$ & $\mathbf{6 9}$ & $\mathbf{7 8}$ & $\mathbf{7 0}$ & $\mathbf{6 8}$ \\
\hline 26 to 49\% more efficient & 12 & 16 & 10 & 22 & 12 & 15 \\
\hline 50\% or greater increase & 54 & 65 & 59 & 56 & 58 & 53 \\
\hline Do not plan to buy new vehicle & $\mathbf{1 1}$ & $\mathbf{2}$ & $\mathbf{1}$ & $\mathbf{0}$ & $\mathbf{2}$ & $\mathbf{3}$ \\
\hline Don't know/don't drive & $\mathbf{2}$ & $*$ & $\mathbf{1}$ & $\mathbf{5}$ & $\mathbf{5}$ & $\mathbf{1}$ \\
\hline Mean (\% more efficient) & $\mathbf{4 3}$ & $\mathbf{4 5}$ & $\mathbf{4 1}$ & $\mathbf{4 3}$ & $\mathbf{4 2}$ & $\mathbf{4 0}$ \\
\hline
\end{tabular}

Source: ORC for NREL (2005b), Study No. 714388, N=1,042

For information on other demographic breakdowns, see Appendix A 
Q2.2.5: If these high gasoline prices continued for the next several years, with respect to driving less, would you say you would reduce the miles you travel by....... (aided question)

Table 2.2.5. Reduction in Miles Traveled (September 2005)

\begin{tabular}{|c|c|c|c|c|c|c|}
\hline Reduction in miles & $\begin{array}{c}\text { Total } \\
(\%)\end{array}$ & $\begin{array}{c}\text { Small } \\
\operatorname{car}(\%)\end{array}$ & $\begin{array}{c}\text { Large } \\
\operatorname{car}(\%)\end{array}$ & $\begin{array}{c}\text { Minivan } \\
(\%)\end{array}$ & $\begin{array}{l}\text { Pickup/ } \\
\operatorname{van}(\%)\end{array}$ & $\begin{array}{l}\text { SUV } \\
(\%)\end{array}$ \\
\hline $25 \%$ or less & 51 & 55 & 54 & 59 & 53 & 62 \\
\hline Less than $5 \%$ & 16 & 15 & 13 & 24 & 17 & 26 \\
\hline 5 to $15 \%$ & 16 & 17 & 18 & 15 & 18 & 19 \\
\hline 16 to $25 \%$ & 19 & 23 & 22 & 20 & 18 & 17 \\
\hline $26 \%$ or more & 31 & 35 & 36 & 29 & 26 & 22 \\
\hline 26 to $49 \%$ & 9 & 8 & 13 & 7 & 10 & 10 \\
\hline $50 \%$ or more & 23 & 26 & 22 & 22 & 16 & 12 \\
\hline None & 12 & 8 & 9 & 12 & 17 & 15 \\
\hline Don't know/don't drive & 5 & 3 & 2 & $\mathbf{0}$ & 5 & 2 \\
\hline Mean (\% reduction in miles) & 23 & 25 & 24 & 21 & 20 & 17 \\
\hline
\end{tabular}

Source: ORC for NREL (2005b), Study No. 714388, N=1,042

For information on other demographic breakdowns, see Appendix A

Q2.2.6: Just your opinion, why would you say the price of gasoline has been increasing so much in recent months? (open-ended question)

Table 2.2.6. Gas Price Increase - Perceived Cause (May 2004)

\begin{tabular}{|l|r|}
\hline Price factor & Percent \\
\hline Big business/oil companies/price gouging/refineries want more profit & 22 \\
\hline The war in Iraq & 19 \\
\hline OPEC/Saudi Arabia manipulating supply & 9 \\
\hline Supply and demand & 8 \\
\hline Government/politics & 7 \\
\hline President Bush & 5 \\
\hline Lack of U.S. refining capability/lack of supply/drilling & 4 \\
\hline Gas shortage/lack of production & 4 \\
\hline Unrest in the Middle East & 4 \\
\hline Economy/inflation & 2 \\
\hline Summer vacation time/prices always go up around this time & 2 \\
\hline Foreign policy & 1 \\
\hline Other & 6 \\
\hline No opinion & 15 \\
\hline
\end{tabular}

Source: Gallup (May 21-23, 2004), N=496

Note: Percentages do not total 100, because each respondent could volunteer more than one response. 
Q2.2.7: Assuming that prices for regular gasoline remain near $\$ 2.50$ per gallon, for your next new vehicle purchase, would you (aided question)

Table 2.2.7. Gas Prices Near $\$ 2.50$ a Gallon and Amount Willing to Pay for New Vehicle (May 2005)

\begin{tabular}{|l|r|}
\hline Type of Vehicle & Percent \\
\hline $\begin{array}{l}\text { Pay an additional \$2,500 to buy a hybrid version of } \\
\text { your vehicle that reduced your gasoline use by } \\
30 \%\end{array}$ & 37 \\
\hline $\begin{array}{l}\text { Pay an additional \$4,000 to buy a plug-in hybrid } \\
\text { version of your vehicle that could reduce your } \\
\text { gasoline use by 45\% if you traveled about } 20 \text { miles } \\
\text { per day on its battery only }\end{array}$ & \\
\hline Neither & 14 \\
\hline Don't know & 44 \\
\hline Total & 4 \\
\hline
\end{tabular}

Source: ORC for NREL (2005a), $\mathrm{N}=1,012$

Q2.2.8: Assuming that prices for regular gasoline decline to and remain at about $\$ 1.50$ per gallon, for your next new vehicle purchase, would you (aided question)

Table 2.2.8. Gas Prices at $\$ 1.50$ a Gallon and Amount Willing to Pay for New Vehicle (May 2005)

\begin{tabular}{|l|c|}
\hline Type of Vehicle & Percent \\
\hline $\begin{array}{l}\text { Pay an additional \$2,500 to buy a hybrid version of } \\
\text { your vehicle that reduced your gasoline use by } \\
30 \%\end{array}$ & 34 \\
\hline $\begin{array}{l}\text { Pay an additional \$4,000 to buy a plug-in hybrid } \\
\text { version of your vehicle that could reduce your } \\
\text { gasoline use by 45\% if you traveled about } 20 \text { miles } \\
\text { per day on its battery only }\end{array}$ & \\
\hline Neither & 10 \\
\hline Don't know & 51 \\
\hline Total & 5 \\
\hline
\end{tabular}

Source: ORC for NREL (2005a), N = 1,012 
Q2.2.9: How high would gasoline prices need to be before you would be willing to pay $\$ 2,000$ more for a vehicle that reduced your gasoline use by a third? Would you say .......... (aided question)

Table 2.2.9. Gas Prices and Willingness to Pay $\$ 2,000$ More for New Vehicle (May 2005)

\begin{tabular}{|l|r|}
\hline Price of gas (per gallon) & Percent \\
\hline$\$ 1.50$ & 12 \\
\hline$\$ 2$ & 8 \\
\hline$\$ 2.50$ & 15 \\
\hline$\$ 3$ or higher & 34 \\
\hline $\begin{array}{l}\text { Never - wouldn't pay \$2,000 more to reduce your } \\
\text { fuel use by a third }\end{array}$ & 22 \\
\hline Don't know & 8 \\
\hline Total & 99 \\
\hline
\end{tabular}

Source: ORC for NREL (2005a), N=1,012 


\subsection{PUBLIC BELIEFS ABOUT ACTIONS TO ADDRESS ENERGY PROBLEMS}

When it comes to opinions regarding priorities for the United States, protecting the environment and developing U.S. energy supplies are nearly equal in the minds of respondents. This trend was supported in surveys conducted by two different groups. (Tables 2.3.2 and 2.3.3).

Q2.3.1: Which of the following approaches to solving the nation's energy problems do you think the United States should follow right now:

Emphasize production of more oil, gas, and coal supplies OR

Emphasize more conservation by consumers of existing energy supplies.

Table 2.3.1. Energy Production Priorities - Production vs. Conservation (2001-05)

\begin{tabular}{|l|c|c|c|c|c|}
\hline Date & $\begin{array}{c}\text { More } \\
\text { production } \\
(\mathbf{\%})\end{array}$ & $\begin{array}{c}\text { More } \\
\text { conservation } \\
(\mathbf{\%})\end{array}$ & $\begin{array}{c}\text { Both/equally } \\
\mathbf{( v o l . )} \\
(\mathbf{\%})\end{array}$ & $\begin{array}{c}\text { Neither/other } \\
(\mathbf{\% o l .}) \\
(\mathbf{\%})\end{array}$ & $\begin{array}{c}\text { No } \\
\text { opinion } \\
(\%)\end{array}$ \\
\hline March 2005 & 28 & 61 & 7 & 2 & 2 \\
\hline March 2004 & 31 & 59 & 6 & 2 & 2 \\
\hline March 2003 & 29 & 60 & 7 & 2 & 2 \\
\hline March 2002 & 30 & 60 & 6 & 1 & 2 \\
\hline March 2001 & 33 & 56 & 8 & 2 \\
\hline
\end{tabular}

Source: Gallup (2001-05), N=496

Q2.3.2: With which one of these statements about the environment and energy production do you most agree:

Protection of the environment should be given priority, even at the risk of limiting the amount of energy supplies (such as oil, gas, and coal), which the United States produces OR

Development of U.S. energy supplies (such as oil, gas, and coal) should be given priority, even if the environment suffers to some extent.

Table 2.3.2. Energy Production Priorities - Environment vs. Supply (2001-05)

\begin{tabular}{|l|c|c|c|c|c|}
\hline Date & $\begin{array}{c}\text { Environment } \\
(\mathbf{\%})\end{array}$ & $\begin{array}{c}\text { Development } \\
\text { of energy } \\
\text { supplies (\%) }\end{array}$ & $\begin{array}{c}\text { Both/equally } \\
\text { (vol.) } \\
(\mathbf{\%})\end{array}$ & $\begin{array}{c}\text { Neither/other } \\
\text { (vol.) } \\
(\mathbf{\%})\end{array}$ & $\begin{array}{c}\text { No } \\
\text { opinion } \\
(\%)\end{array}$ \\
\hline March 2005 & 52 & 39 & 4 & 2 & 3 \\
\hline March 2004 & 48 & 44 & 3 & 1 & 4 \\
\hline March 2003 & 49 & 40 & 5 & 2 & 4 \\
\hline March 2002 & 52 & 40 & 3 & 2 & 3 \\
\hline March 2001 & 52 & 36 & 6 & 2 & 4 \\
\hline
\end{tabular}

Source: Gallup (2001-05), N=496 
Which Should be Given Priority - Protection of the

Environment or Development of U.S. Energy Supplies?

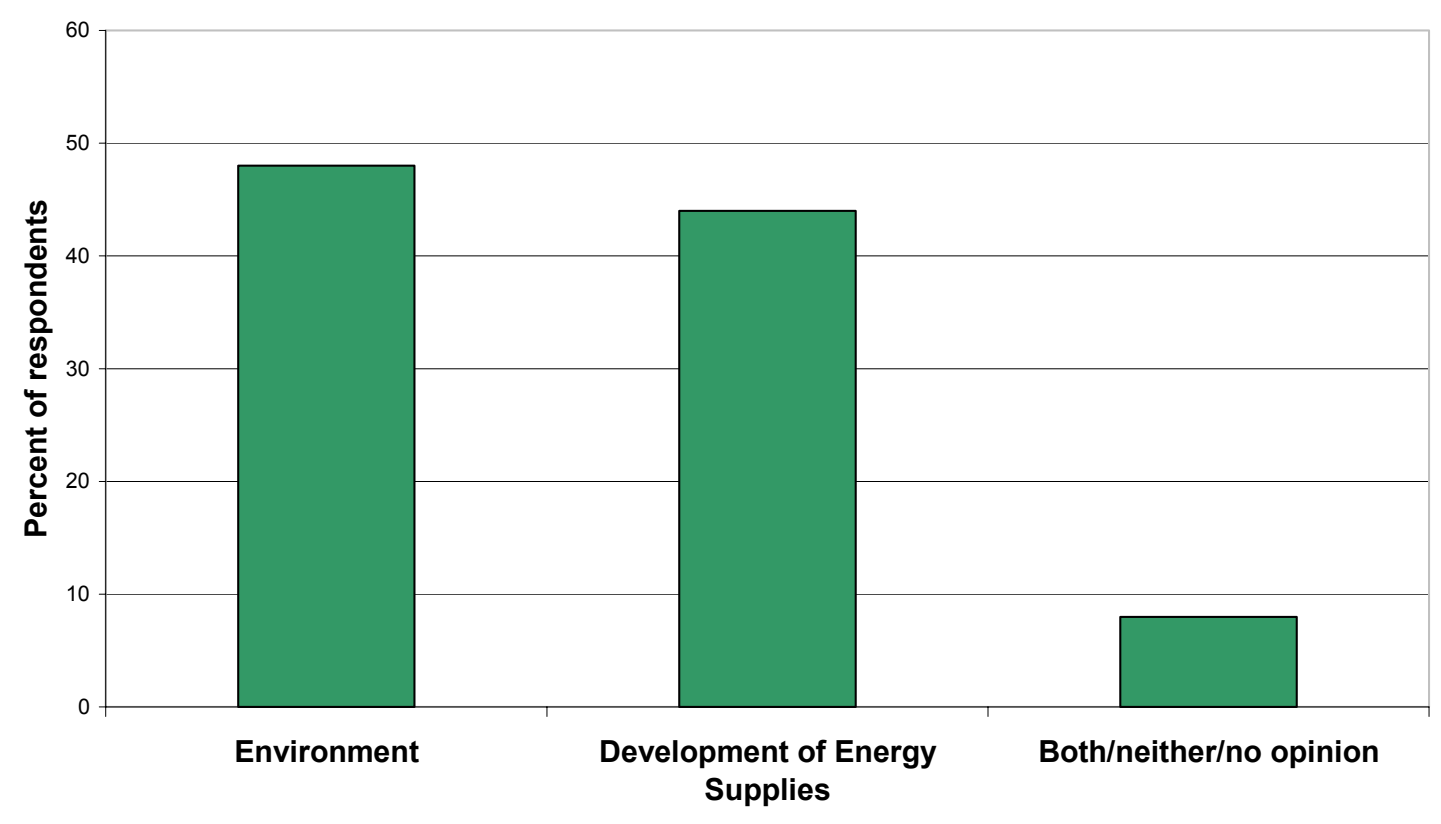

Source: Gallup (March 2004)

Q2.3.3: Right now, which one of the following do you think should be a more important priority for this country: protecting the environment or developing new sources of energy?

Table 2.3.3. Priorities for the Country (selected years, 2001-05)

\begin{tabular}{|l|c|c|c|}
\hline Date & $\begin{array}{c}\text { Environment } \\
(\mathbf{\%})\end{array}$ & $\begin{array}{c}\text { Energy } \\
\mathbf{( \% )}\end{array}$ & $\begin{array}{c}\text { Unsure } \\
(\mathbf{\%})\end{array}$ \\
\hline March 2005 & 42 & 49 & 9 \\
\hline February 2002 & 45 & 48 & 7 \\
\hline May 2001 & 42 & 49 & 9 \\
\hline
\end{tabular}

Source: Princeton Survey (March 2005), N=750 
Q2.3.4: Do you favor or oppose relaxing some environmental standards to increase oil and gas production in the United States?

Table 2.3.4. Relaxing Environmental Standards (April 2004)

\begin{tabular}{|l|c|c|c|}
\hline Political affiliation & $\begin{array}{c}\text { Favor } \\
(\mathbf{\%})\end{array}$ & $\begin{array}{c}\text { Oppose } \\
(\mathbf{\%})\end{array}$ & $\begin{array}{c}\text { Unsure } \\
(\mathbf{\%})\end{array}$ \\
\hline All & $\mathbf{4 6}$ & $\mathbf{4 3}$ & $\mathbf{1 1}$ \\
\hline Democrats & 34 & 54 & 12 \\
\hline Republicans & 63 & 26 & 11 \\
\hline Independents & 40 & 49 & 11 \\
\hline
\end{tabular}

Source: Fox News/Opinion Dynamics Poll (April 2004), N=900

Q2.3.5: Do you think that in the past few years the environmental regulations in the United States have become more strict, have stayed about the same, or have gotten looser? (aided question)

Table 2.3.5. View of Strictness of Environmental Regulations (May 2005)

\begin{tabular}{|l|c|}
\hline Environmental regulations & Percent \\
\hline Much more strict & 12 \\
\hline Somewhat more strict & 20 \\
\hline Stayed about the same & 26 \\
\hline Somewhat looser & 21 \\
\hline Much looser & 17 \\
\hline Don't know & 5 \\
\hline
\end{tabular}

Source: Yale Environment Survey (May 2005), N=1,002

Q2.3.6: Right now, do you think the quality of the environment is getting better, staying about the same, or getting worse? (aided question)

Table 2.3.6. Quality of the Environment at Various Levels (May 2005)

\begin{tabular}{|l|c|c|c|c|}
\hline Level & $\begin{array}{c}\text { Getting } \\
\text { better } \\
\mathbf{( \% )}\end{array}$ & $\begin{array}{c}\text { Staying } \\
\text { about the } \\
\text { same }(\mathbf{\%})\end{array}$ & $\begin{array}{c}\text { Getting } \\
\text { worse } \\
\mathbf{( \% )}\end{array}$ & $\begin{array}{c}\text { Don't } \\
\text { know } \\
(\mathbf{\%})\end{array}$ \\
\hline In your community & 17 & 54 & 28 & 1 \\
\hline In the United States & 16 & 33 & 50 & 1 \\
\hline Worldwide & 10 & 22 & 63 & 5 \\
\hline
\end{tabular}

Source: Yale Environment Survey (May 2005), N=1,002 
Q2.3.7: I am going to read some specific environmental proposals. For each one, please say whether you generally favor or oppose it.

Table 2.3.7. Environmental Proposals (March 2003)

\begin{tabular}{|l|c|c|c|}
\hline Proposal & Favor (\%) & $\begin{array}{c}\text { Oppose } \\
(\mathbf{\%})\end{array}$ & $\begin{array}{c}\text { No opinion } \\
\text { (\%) }\end{array}$ \\
\hline $\begin{array}{l}\text { Setting higher emissions and pollution } \\
\text { standards for business and industry }\end{array}$ & 80 & 19 & 1 \\
\hline $\begin{array}{l}\text { Imposing mandatory controls on carbon } \\
\text { dioxide emissions and other greenhouse gases }\end{array}$ & 75 & 22 & 3 \\
\hline $\begin{array}{l}\text { More strongly enforcing federal environmental } \\
\text { regulations }\end{array}$ & 75 & 21 & 4 \\
\hline $\begin{array}{l}\text { Setting higher auto emissions standards for } \\
\text { automobiles }\end{array}$ & 73 & 24 & 6 \\
\hline Expanding the use of nuclear energy & 43 & 51 & 4 \\
\hline $\begin{array}{l}\text { Opening up the Arctic National Wildlife } \\
\text { Refuge in Alaska for oil exploration }\end{array}$ & & 55 & \\
\hline
\end{tabular}

Source: Gallup (March 2003), N=526

Q2.3.8: Regarding some possible ways of reducing U.S. dependence on imported oil, do you think the following are a good idea or a bad idea? (aided question)

Table 2.3.8. Ideas for Reducing Dependence on Imported Oil (May 2005)

\begin{tabular}{|c|c|c|c|}
\hline Idea (Top 10 Responses) & Good (\%) & $\operatorname{Bad}(\%)$ & $\begin{array}{l}\text { OK/Can't } \\
\text { Rate }(\%)\end{array}$ \\
\hline $\begin{array}{l}\text { Require the auto industry to make cars that get better } \\
\text { gas mileage }\end{array}$ & 93 & 6 & 1 \\
\hline $\begin{array}{l}\text { Require the auto industry to make more fuel-efficient } \\
\text { cars }\end{array}$ & 90 & 8 & 1 \\
\hline Build more solar power facilities & 90 & 6 & 3 \\
\hline $\begin{array}{l}\text { Build more wind-turbine farms to harness wind- } \\
\text { generated electricity }\end{array}$ & 87 & 6 & 6 \\
\hline Increase funding for renewable energy research & 86 & 9 & 4 \\
\hline $\begin{array}{l}\text { Provide tax credits to people who buy more energy- } \\
\text { efficient appliances such as air conditioning, clothes } \\
\text { dryers, and water heaters }\end{array}$ & 84 & 13 & 3 \\
\hline Promote the development of hydrogen-powered cars & 81 & 8 & 11 \\
\hline Build more water-powered hydroelectric facilities & 81 & 11 & 8 \\
\hline $\begin{array}{l}\text { Provide tax credits to people who buy cars that get } \\
\text { good gas mileage }\end{array}$ & 79 & 19 & 2 \\
\hline Promote the use of hydrogen fuel cell technology & 71 & 8 & 20 \\
\hline
\end{tabular}

Source: Yale Environment Survey (May 2005), N=1,002 


\section{ALTERNATIVE FUELS}

A number of surveys researched the U.S. adult population knowledge and opinions about alternative types of fuel such as electricity, ethanol, and hydrogen. Poll questions asked between 2000 and 2005 focused on knowledge and opinions about alternative fuels. Several of these survey questions demonstrate that opinions regarding safety and environmental attributes of these fuel sources have changed from 2000 to 2005.

Table 3.1.1. Factors Considered "Extremely Important" or "Very Important" in Influencing Decisions to Try a New Fuel Technology (2003)

\begin{tabular}{|l|c|}
\hline Factor & Percent \\
\hline How safe the fuel is for drivers and passengers & 83 \\
\hline The cost of the fuel & 78 \\
\hline How far you can drive before refueling & 75 \\
\hline The cost of the vehicle & 72 \\
\hline The convenience of refueling & 67 \\
\hline Environmental emissions & 67 \\
\hline Whether the fuel source is domestic instead of foreign & 47 \\
\hline How the new fuel system affects passenger and cargo space & 47 \\
\hline Whether or not the fuel can be recycled & 45 \\
\hline
\end{tabular}

Source: Harris poll for Millennium Cell and U.S. Borax Inc. (2003), N=1,006.

Q3.1.2: Consider a future date when gasoline is no longer available. Which of the following do you think would be the best fuel for use in personal vehicles: electricity, ethanol, or hydrogen?

Table 3.1.2. Public Perception of Best Fuel and Worst Fuel for Use in Personal Vehicles When Gasoline Is No Longer Available (2000 and 2004)

\begin{tabular}{|l|r|r|r|r|}
\hline $\begin{array}{l}\text { Fuel for Use in } \\
\text { Personal Vehicles }\end{array}$ & \multicolumn{2}{|c|}{$\begin{array}{c}\text { Best Fuel } \\
\text { (\%) }\end{array}$} & \multicolumn{2}{c|}{$\begin{array}{c}\text { Worst Fuel } \\
\text { (\%) }\end{array}$} \\
\hline & $\mathbf{2 0 0 0}$ & $\begin{array}{c}\text { August } \\
\mathbf{2 0 0 4}\end{array}$ & $\mathbf{2 0 0 0}$ & $\begin{array}{c}\text { August } \\
\mathbf{2 0 0 4}\end{array}$ \\
\hline Electricity & 52 & 41 & 15 & 21 \\
\hline Hydrogen & 15 & 28 & 27 & 23 \\
\hline Ethanol & 21 & 19 & 28 & 28 \\
\hline Don't know & 12 & 13 & 30 & 29 \\
\hline Total & 100 & 100 & 100 & 100 \\
\hline
\end{tabular}

Source: ORC for NREL (2000b), Study No. 709489, N=1,000; and ORC for NREL (2004b), Study No. 713359, N=1,000. 
Q3.1.3: Why did you say electricity would be the best fuel for use in personal vehicles when gasoline is no longer available? (unaided question)

Table 3.1.3. Reasons Electricity Would Be the Best Fuel for Use in Personal Vehicles When Gasoline Is No Longer Available (2000 and 2004)

\begin{tabular}{|l|r|r|}
\hline \multirow{2}{*}{ Reasons } & \multicolumn{2}{|c|}{ Percent } \\
\cline { 2 - 3 } & $\mathbf{2 0 0 0}$ & $\begin{array}{c}\text { August } \\
\mathbf{2 0 0 4}\end{array}$ \\
\hline $\begin{array}{l}\text { Environmental concerns (cleaner, less pollution, cleaner air, other } \\
\text { environmental mentions) }\end{array}$ & 29 & 23 \\
\hline $\begin{array}{l}\text { Availability (abundant, common, renewable/inexhaustable, easy } \\
\text { to produce/manufacture, not dependent on foreign oil) }\end{array}$ & 22 & 23 \\
\hline $\begin{array}{l}\text { Existing/developing technology (electric cars already being } \\
\text { developed, technology already being used, many things powered } \\
\text { by electricity) }\end{array}$ & & \\
\hline Economical/affordable & 17 & \\
\hline $\begin{array}{l}\text { Methods of generating (can be solar generated/powered, other } \\
\text { related mentions) }\end{array}$ & 11 & \\
\hline Most familiar with it/not familiar with others & 7 & \\
\hline Safe & 7 & 3 \\
\hline Other & 5 & 8 \\
\hline Don't know & 5 & 9 \\
\hline
\end{tabular}

Source: ORC for NREL (2000b), Study No. 709489, N=522; and ORC for NREL (2004b), Study No. $713359, \mathrm{~N}=1,000$.

Note: Percentages do not total 100, because each respondent could volunteer more than one response. 
Q3.1.4: Why did you say ethanol would be the best fuel for use in personal vehicles when gasoline is no longer available?

Table 3.1.4. Reasons Ethanol Would Be the Best Fuel for Use in Personal Vehicles When Gasoline Is No Longer Available (2000 and 2004)

\begin{tabular}{|l|r|r|}
\hline \multirow{2}{*}{ Reasons } & \multicolumn{2}{|c|}{ Percent } \\
\cline { 2 - 3 } & $\mathbf{2 0 0 0}$ & $\begin{array}{c}\text { August } \\
\mathbf{2 0 0 4}\end{array}$ \\
\hline $\begin{array}{l}\text { Readily available (common, abundant, renewable/inexhaustible, easy } \\
\text { to produce/manufacture, can generate our own fuel, other mentions) }\end{array}$ & & \\
\hline Methods of generating (made from corn/grain, other related mentions) & 27 & 28 \\
\hline Economical/affordable & 18 & 12 \\
\hline $\begin{array}{l}\text { Environmental concerns (cleaner, less pollution, other related } \\
\text { mentions) }\end{array}$ & 15 & \\
\hline Others not practical/performance concerns & 15 & 15 \\
\hline Better for/helps farmers/ farming industry & 10 & 6 \\
\hline Existing/developing technology & 8 & 14 \\
\hline Best source (unspecified) & 8 & 9 \\
\hline More similar to gasoline & 5 & 11 \\
\hline Other & 5 & 6 \\
\hline Don't know & 12 & 5 \\
\hline
\end{tabular}

Source: ORC for NREL (2000b), Study No. 709489, N=206; and ORC for NREL (2004b), Study No. $713359, \mathrm{~N}=1,000$.

Note: Percentages do not total 100, because each respondent could volunteer more than one response.

Q3.1.5: Why did you say hydrogen would be the best fuel for use in personal vehicles when gasoline is no longer available?

Table 3.1.5. Reasons Hydrogen Would Be the Best Fuel for Use in Personal Vehicles When Gasoline Is No Longer Available (2000 and 2004)

\begin{tabular}{|l|r|r|}
\hline \multirow{2}{*}{ Reasons } & \multicolumn{2}{|c|}{ Percent } \\
\cline { 2 - 3 } & $\mathbf{2 0 0 0}$ & $\begin{array}{c}\text { August } \\
\mathbf{2 0 0 4}\end{array}$ \\
\hline $\begin{array}{l}\text { Availability (common, abundant, easy to produce/manufacture, } \\
\text { renewable/inexhaustible, other related mentions) }\end{array}$ & 37 & \\
\hline Environmental concerns (cleaner, less pollution, other related mentions) & 27 & 24 \\
\hline Economical/affordable & 12 & 16 \\
\hline Others not practical/ performance concerns & 11 & 6 \\
\hline Existing/developing technology (net) & 7 & 6 \\
\hline More efficient & 5 & 1 \\
\hline Safety concerns & 5 & 1 \\
\hline Best source (unspecified) & 3 & 2 \\
\hline Other & 9 & 9 \\
\hline Don't know & 9 & 8 \\
\hline
\end{tabular}

Source: ORC for NREL (2000b), Study No. 709489, N=151; and ORC for NREL (2004b), Study No. $713359, \mathrm{~N}=1,000$.

Note: Percentages do not total 100 , because each respondent could volunteer more than one response. 
Q3.1.6: Why did you say electricity would be the worst fuel for use in personal vehicles when gasoline is no longer available?

Table 3.1.6. Reasons Electricity Would Be the Worst Fuel for Use in Personal Vehicles When Gasoline Is No Longer Available (2000 and 2004)

\begin{tabular}{|l|r|r|}
\hline \multirow{2}{*}{ Reasons } & \multicolumn{2}{|c|}{ Percent } \\
\cline { 2 - 3 } & $\mathbf{2 0 0 0}$ & $\begin{array}{c}\text { August } \\
\mathbf{2 0 0 4}\end{array}$ \\
\hline Too expensive & 28 & 23 \\
\hline Electric vehicles can't hold charge for long/can't travel long distances & 20 & 9 \\
\hline $\begin{array}{l}\text { Environmental concerns (must burn coal/fossil fuels, pollution, other } \\
\text { related mentions) }\end{array}$ & 19 & \\
\hline Not enough electricity now & 12 & 23 \\
\hline Safety concerns & 5 & 6 \\
\hline Other & 15 & 9 \\
\hline Don't know & 10 & 13 \\
\hline
\end{tabular}

Source: ORC for NREL (2000b), Study No. 709489, N=150; and ORC for NREL (2004b), Study No. $713359, \mathrm{~N}=1,000$.

Note: Percentages do not total 100, because each respondent could volunteer more than one response.

Q3.1.7: Why did you say ethanol would be the worst fuel for use in personal vehicles when gasoline is no longer available?

Table 3.1.7. Reasons Ethanol Would Be the Worst Fuel for Use in Personal Vehicles When Gasoline Is No Longer Available (2000 and 2004)

\begin{tabular}{|l|r|r|}
\hline \multirow{2}{*}{ Reasons } & \multicolumn{2}{|c|}{ Percent } \\
\cline { 2 - 3 } & $\mathbf{2 0 0 0}$ & \multicolumn{2}{|c|}{$\begin{array}{c}\text { August } \\
\mathbf{2 0 0 4}\end{array}$} \\
\hline $\begin{array}{l}\text { Environmental concerns (pollution, creates environmental } \\
\text { problems, other related mentions) }\end{array}$ & 38 & \\
\hline $\begin{array}{l}\text { Safety concerns (flammable/combustible, explosive, contains } \\
\text { chemicals, other related mentions) }\end{array}$ & & 30 \\
\hline Too expensive & 20 & 12 \\
\hline Lack of availability & 6 & 4 \\
\hline Finite/exhaustible resource & 4 & 4 \\
\hline Difficult to produce & 3 & 2 \\
\hline Causes engine trouble & 3 & 3 \\
\hline Other & 3 & 1 \\
\hline Don't know & 13 & 7 \\
\hline
\end{tabular}

Source: ORC for NREL (2000b), Study No. 709489, N=281; and ORC for NREL (2004b), Study No. 713359, $\mathrm{N}=1,000$.

Note: Percentages do not total 100, because each respondent could volunteer more than one response. 
Q3.1.8: Why did you say hydrogen would be the worst fuel for use in personal vehicles when gasoline is no longer available?

Table 3.1.8. Reasons Hydrogen Would Be the Worst Fuel for Use in Personal Vehicles When Gasoline Is No Longer Available (2000 and 2004)

\begin{tabular}{|l|r|r|}
\hline \multirow{2}{*}{ Reasons } & \multicolumn{2}{|c|}{ Percent } \\
\cline { 2 - 3 } & $\mathbf{2 0 0 0}$ & $\begin{array}{c}\text { August } \\
\mathbf{2 0 0 4}\end{array}$ \\
\hline $\begin{array}{l}\text { Safety concerns (explosive, flammable/combustible, unstable, think of } \\
\text { bombs, other related mentions) }\end{array}$ & 50 & \\
\hline Pollution and environmental concerns & 8 & 40 \\
\hline Not enough is known about it & 4 & 5 \\
\hline Difficult to produce & 4 & 4 \\
\hline Too expensive & 3 & 1 \\
\hline Other & 15 & 9 \\
\hline Don't know & 21 & 23 \\
\hline
\end{tabular}

Source: ORC for NREL (2000b), Study No. 709489, N=274; and ORC for NREL (2004b), Study No. $713359, \mathrm{~N}=1,000$. 


\section{CONVENTIONAL, MORE FUEL-EFFICIENT, AND ADVANCED- TECHNOLOGY VEHICLES}

Section 4 focuses on vehicle owners and the decisions they make about their vehicles. It consists of three sections that encompass survey data on owners' decisions about their conventional (i.e., gasoline) vehicles, as well as more fuel-efficient and advanced-technology vehicles.

\subsection{VEHICLE OWNERS' DECISIONS ON CONVENTIONAL VEHICLES}

Q4.1.1: Which of the following attributes would be MOST important to you in your choice of your next vehicle? (closed-ended)

Table 4.1.1. Trends in Vehicle-Attribute Preference (selected years, 1980-2005)

\begin{tabular}{|l|r|r|r|r|r|r|r|r|r|r|r|}
\hline & \multicolumn{4}{|c|}{ J.D. Power (percent) } & \multicolumn{5}{c|}{ ORC (percent) } \\
\hline Attributes & $\mathbf{1 9 8 0}$ & $\mathbf{1 9 8 1}$ & $\mathbf{1 9 8 3}$ & $\mathbf{1 9 8 5}$ & $\mathbf{1 9 8 7}$ & $\mathbf{1 9 9 6}$ & $\mathbf{1 9 9 8}$ & $\mathbf{2 0 0 0}$ & $\mathbf{2 0 0 1}$ & $\begin{array}{l}\text { May } \\
\mathbf{2 0 0 4}\end{array}$ & $\begin{array}{c}\text { May } \\
\mathbf{2 0 0 5}\end{array}$ \\
\hline Fuel economy & 42 & 20 & 13 & 8 & 4 & 7 & 4 & 10 & 10 & 22 & 12 \\
\hline Dependability & 31 & 40 & 38 & 41 & 44 & 34 & 36 & 32 & 29 & 26 & 33 \\
\hline Low price & 14 & 21 & 30 & 29 & 31 & 11 & 5 & 11 & 8 & 10 & 6 \\
\hline Quality & 4 & 7 & 11 & 12 & 8 & 19 & 20 & 21 & 22 & 19 & 20 \\
\hline Safety & 9 & 12 & 9 & 10 & 14 & 29 & 34 & 24 & 29 & 23 & 26 \\
\hline $\begin{array}{l}\text { Don't know/ } \\
\text { none of these }\end{array}$ & & & & & & & 1 & 2 & 1 & & 3 \\
\hline Total & 100 & 100 & 100 & 100 & 101 & 100 & 100 & 100 & 99 & 100 & 100 \\
\hline
\end{tabular}

Sources: For 1980s: J. D. Power (data based on new-car buyers). For 1996: ORC for NREL. For 1998: ORC for NREL (1998a), $N=1,000$. For 2000: ORC for NREL (2000a), $\mathrm{N}=$ 941. For 2001: ORC for NREL (2001c), $\mathrm{N}=989$. For 2004: ORC for NREL (2004a), $\mathrm{N}=949$. For 2005: ORC for NREL (2005a), $\mathrm{N}=1,012$.

In-market car buyers were asked about their views toward sport utility vehicles (SUVs).

Table 4.1.2. Issue Is a Major Reason for Those NOT Considering the Purchase of an SUV (2003)

\begin{tabular}{|l|c|c|}
\hline Issue & $\begin{array}{c}\text { January } \\
\mathbf{2 0 0 3}\end{array}$ & $\begin{array}{c}\text { March } \\
\mathbf{2 0 0 3}\end{array}$ \\
\hline Price of gas & -- & 50 \\
\hline Not the kind of vehicle I want & 51 & 45 \\
\hline Rollover/safety concerns & 30 & 34 \\
\hline Impact on foreign oil dependence & 28 & 31 \\
\hline Impact on environment & 25 & 26 \\
\hline Too big for the road & 23 & 23 \\
\hline Source: Kell Bly Bok & & \\
\hline
\end{tabular}

Source: Kelley Blue Book (2003), N=524 


\subsection{VEHICLE OWNERS' DECISIONS ABOUT MORE FUEL-EFFICIENT VEHICLES}

Q4.2.1: $\quad$ Suppose that the next vehicle you've decided to buy offers an option of better fuel economy, but at a higher price. The savings in fuel costs would pay back the higher price over time. How soon, in years, would the fuel savings have to pay back the additional cost to persuade you to buy the higher fuel-economy option?

Table 4.2.1. Number of Years Public is Willing to Accept for Payback of Higher Fuel-Economy Vehicle (2002)

\begin{tabular}{|l|r|}
\hline Years & Percent \\
\hline 1 & 18 \\
\hline 2 & 23 \\
\hline 3 & 13 \\
\hline 4 & 3 \\
\hline 5 & 12 \\
\hline 6 & - \\
\hline More than 6 & 3 \\
\hline Don't Know & 27 \\
\hline Total & 100 \\
\hline Mean & 2.9 \\
\hline
\end{tabular}

Source: ORC for NREL (2002b), N=1,000

Q4.2.2: How much more would you be willing to pay for the vehicle that gets $10 \%$ better fuel economy than for the vehicle you currently drive?

Table 4.2.2. Additional Amount the Public is Willing to Pay for a Vehicle with a 10 Percent Increase in Fuel Economy (2001)

\begin{tabular}{|l|r|}
\hline Dollar Amount & Percent \\
\hline Less than $\$ 500$ & 7 \\
\hline$\$ 500-\$ 1,000$ & 15 \\
\hline$\$ 1,001-\$ 2,500$ & 17 \\
\hline$\$ 2,501-\$ 5,000$ & 15 \\
\hline More than \$5,000 & 5 \\
\hline Nothing more & 18 \\
\hline Don't know & 23 \\
\hline Total & 100 \\
\hline Mean' (including none) & $\$ 2,143$ \\
\hline Mean 1 (excluding none) & $\$ 2,799$ \\
\hline
\end{tabular}

Source: ORC for NREL (2001b), Study No. 710449, N=180

${ }^{1}$ In this report, calculation of means, medians, and standard deviations are based on raw numbers. "Don't know" responses are not part of the calculations. 
Q4.2.3: Suppose you have decided to buy a new vehicle and have a choice of an optional engine that requires a new fuel that costs the same as gasoline and is just as good as gasoline.

Version A: The optional engine costs the same as the conventional one but gets $50 \%$ more miles per gallon. However, the fuel it requires is sold only at 1 in 10 stations. Which would you most likely buy?

Version B: The optional engine costs the same as the conventional one but gets $50 \%$ more miles per gallon. However, the fuel it requires is sold only at 1 in 5 stations. Which would you most likely buy?

Version C: The optional engine costs the same as the conventional one but gets $50 \%$ more miles per gallon. However, the fuel it requires is sold only at 1 in 3 stations. Which would you most likely buy?

Table 4.2.3. Public Preference Toward Purchasing a More Fuel-Efficient Engine with Different Fuel-Availability Options (2000)

\begin{tabular}{|c|l|c|c|c|}
\hline \multicolumn{2}{|c|}{ Fuel-Availability Options } & $\begin{array}{c}\text { Conventional } \\
\text { Engine } \\
(\%)\end{array}$ & $\begin{array}{c}\text { Optional } \\
\text { Engine } \\
(\%)\end{array}$ & $\begin{array}{c}\text { Don't } \\
\text { Know/Refused } \\
\text { (\%) }\end{array}$ \\
\hline A & $\begin{array}{l}\text { The optional engine costs the same as } \\
\text { the conventional one, but gets 50\% } \\
\text { more miles per gallon. However, the } \\
\text { fuel it requires is sold only at 1 in 10 } \\
\text { stations. }\end{array}$ & 66 & 30 & 4 \\
\hline B & $\begin{array}{l}\text { The optional engine costs the same as } \\
\text { the conventional one, but gets 50\% } \\
\text { more miles per gallon. However, the } \\
\text { fuel it requires is sold only at 1 in 5 } \\
\text { stations. }\end{array}$ & 62 & 36 & 4 \\
\hline C & $\begin{array}{l}\text { The optional engine costs the same as } \\
\text { the conventional one, but gets 50\% } \\
\text { more miles per gallon. However, the } \\
\text { fuel it requires is sold only at 1 in 3 } \\
\text { stations. }\end{array}$ & 43 & 53 & 4 \\
\hline
\end{tabular}

Source: ORC for NREL (2000d), Study No. 70920, N=111 


\subsection{VEHICLE OWNERS' DECISIONS ABOUT ADVANCED-TECHNOLOGY VEHICLES}

\section{Hybrid-Electric Vehicles}

Q4.3.1: There are some vehicles in the U.S. market today that have hybrid-electric powertrains that combine an electric motor and a gasoline engine to achieve a higher fuel economy than similar-sized vehicles. Please name one of these hybrid vehicles, if you can.

Table 4.3.1. Names of Advanced Hybrid-Electric Vehicles Known by the Public (selected years, 2000-04)

\begin{tabular}{|l|c|c|c|c|}
\hline \multirow{2}{*}{} & \multicolumn{4}{|c|}{ Percent } \\
\cline { 2 - 5 } & August 2000 & November 2001 & November 2002 & May 2004 \\
\hline Any vehicle & 36 & 44 & 51 & 48 \\
\hline Honda & 15 & 24 & 24 & 17 \\
\hline Toyota & 4 & 11 & 10 & 6 \\
\hline Ford & NA & NA & NA & 4 \\
\hline Other & 14 & 6 & 7 & 52 \\
\hline Don't Know & 64 & 56 & 48 & 9 \\
\hline
\end{tabular}

Source: ORC for NREL (2000) N=953, (2001) N=999, (2002c) N=999, (2000a) N=1,000, (2004a) $\mathrm{N}=1,000$

Note: Percentages do not total 100, because each respondent could volunteer more than one response.

A 2003 survey of in-market consumers by Kelley Blue Book examined the influence of the media on attitudes toward SUVs. Although no hybrid-electric SUVs were available in the United States at the time of this survey (mid-2003), shoppers would think favorably of such an option and might be more likely to consider the purchase of an SUV.

Table 4.3.2. Public's Attitudes Toward Hybrid-Electric SUVs (2003)

\begin{tabular}{|l|r|r|r|r|r|r|}
\hline & \multicolumn{9}{|c|}{ Percent } \\
\cline { 2 - 8 } & \multicolumn{2}{|c|}{ SUV Considerers } & \multicolumn{2}{c|}{$\begin{array}{c}\text { SUV } \\
\text { Non-Considerers }\end{array}$} & \multicolumn{2}{c|}{ Total } \\
\cline { 2 - 8 } & Jan 2003 & Mar 2003 & Jan 2003 & Mar 2003 & Jan 2003 & Mar 2003 \\
\hline $\begin{array}{l}\text { More favorable } \\
\text { toward SUVs }\end{array}$ & 52 & 46 & 45 & 44 & 48 & 45 \\
\hline Neutral & 40 & 46 & 44 & 51 & 42 & 49 \\
\hline $\begin{array}{l}\text { Less favorable } \\
\text { toward SUVs }\end{array}$ & 8 & 7 & 11 & 5 & 10 & 6 \\
\hline
\end{tabular}

Source: Kelley Blue Book (2003), N=524 
Q4.3.3: $\quad$ Suppose you were going to buy a new vehicle. Would you seriously consider buying a car or SUV that is a gas-electric hybrid, or not? If the hybrid vehicle cost $\$ 3,000$ more than the standard model of the same vehicle would you still seriously consider buying it, or not?

Table 4.3.3. Level of Consideration for Gas-Electric Hybrid (August 2005)

\begin{tabular}{|l|r|}
\hline Response & Percent \\
\hline Yes, seriously consider & $\mathbf{5 5}$ \\
\hline Even if $\$ 3,000$ more & 45 \\
\hline Not, if $\$ 3,000$ more & 9 \\
\hline No, would not & $\mathbf{4 3}$ \\
\hline No opinion & $\mathbf{2}$ \\
\hline
\end{tabular}

Source: Gallup (August 2005), N=1,007

Q4.3.4: When you buy or lease your next vehicle, will the car's gas mileage be a more important consideration for you that it has been in the past, or will it not be any more important to you?

Table 4.3.4. Importance of Gas Mileage in Next Vehicle (August 2005)

\begin{tabular}{|l|r|}
\hline Response & Percent \\
\hline More important & 75 \\
\hline Not more important & 22 \\
\hline Less important & $*$ \\
\hline Don't drive & 1 \\
\hline No opinion & 2 \\
\hline
\end{tabular}

Source: Gallup (August 2005), N=1,007 


\section{Diesel Vehicles}

Q4.3.5: What fuels would you like to see replace gasoline and diesel fuel in the vehicles used in the United States? Anything else? (unaided question)

Table 4.3.5. Alternative Fuels to Replace Gasoline and Diesel Fuel in Vehicles

(September 2005)

\begin{tabular}{|l|c|c|c|c|c|r|}
\hline Response & $\begin{array}{c}\text { Total } \\
(\mathbf{\%})\end{array}$ & $\begin{array}{c}\text { Small car } \\
\mathbf{( \% )}\end{array}$ & $\begin{array}{c}\text { Large } \\
\text { car (\%) }\end{array}$ & $\begin{array}{c}\text { Minivan } \\
\mathbf{( \% )}\end{array}$ & $\begin{array}{c}\text { Pickup/ } \\
\text { van (\%) }\end{array}$ & $\begin{array}{c}\text { SUV } \\
\text { (\%) }\end{array}$ \\
\hline Electricity & 14 & 18 & 18 & 15 & 13 & 9 \\
\hline Hydrogen & 14 & 21 & 16 & 15 & 15 & 11 \\
\hline Ethanol & 11 & 13 & 11 & 11 & 10 & 11 \\
\hline Solar & 7 & 6 & 10 & 11 & 10 & 7 \\
\hline Water & 7 & 6 & 8 & 11 & 3 & 8 \\
\hline Hybrid fuel/cars & 5 & 9 & 7 & 3 & 7 & 3 \\
\hline Corn & 5 & 4 & 6 & 8 & 4 & 4 \\
\hline Vegetable oil & 3 & 3 & 2 & 4 & 4 & 5 \\
\hline Natural gas & 3 & 2 & 4 & 1 & 3 & 3 \\
\hline Alcohol & 2 & 4 & 3 & 1 & 3 & 1 \\
\hline Diesel & 2 & 2 & $*$ & 2 & 4 & 2 \\
\hline Fuel cells (unspecified) & 2 & 3 & 3 & 2 & 1 & 1 \\
\hline Batteries & 2 & 2 & 4 & 1 & 1 & 1 \\
\hline Propane & 1 & 2 & 1 & 2 & 4 & 0 \\
\hline $\begin{array}{l}\text { Something } \\
\text { environmentally friendly }\end{array}$ & 1 & 2 & 3 & 0 & 1 & 1 \\
\hline $\begin{array}{l}\text { Anything cheaper/less } \\
\text { expensive }\end{array}$ & 1 & $*$ & 1 & 2 & 1 & 3 \\
\hline Bio-diesel & 1 & 1 & $*$ & 0 & 3 & $*$ \\
\hline Cooking oil & 1 & 2 & $*$ & 0 & 1 & 0 \\
\hline Nuclear & 1 & 1 & 2 & 0 & 0 & 1 \\
\hline Soy/soybeans & 1 & 1 & $*$ & 1 & 1 & $*$ \\
\hline Methanol & 1 & $*$ & 1 & 0 & 1 & $*$ \\
\hline Wind & 1 & $*$ & $*$ & 0 & 1 & 0 \\
\hline Other & 11 & 8 & 11 & 12 & 12 & 13 \\
\hline Soire: & & & & & \\
\hline
\end{tabular}

Source: ORC for NREL (2005b), Study No. $714388, \mathrm{~N}=1,042$

Note: Percentages do not total 100, because each respondent could volunteer more than one response 
Q4.3.6: Would you consider buying a diesel engine version that got $40 \%$ better fuel economy and costs an additional $\$ 1,500$ ?

Table 4.3.6 Public's Willingness to Pay a Premium for a Clean Diesel Engine (2002)

\begin{tabular}{|l|r|l|r|}
\hline \multirow{2}{*}{$\begin{array}{l}\text { Premium Willing to Pay } \\
\text { For Clean Diesel }\end{array}$} & Total & $\begin{array}{l}|c| \\
\text { Current Diesel } \\
\text { Owner }\end{array}$ & $\begin{array}{l}\text { Percent } \\
\text { Current Gas } \\
\text { Owner }\end{array}$ \\
\cline { 2 - 5 } & 33 & 10 & 34 \\
\hline$\$ 0$ & 8 & 4 & 8 \\
\hline$\$ 1-\$ 199$ & 7 & 1 & 7 \\
\hline$\$ 200-\$ 399$ & 16 & 8 & 17 \\
\hline$\$ 400-\$ 599$ & 4 & 3 & 4 \\
\hline$\$ 600-\$ 999$ & 14 & 17 & 14 \\
\hline$\$ 1,000-\$ 1,499$ & 4 & 5 & 4 \\
\hline$\$ 1,500-\$ 1,999$ & 14 & 51 & 12 \\
\hline More than $\$ 2,000$ & & & \multicolumn{3}{|c|}{} \\
\hline
\end{tabular}

Source: J.D. Power and Associates (2002), N-not available

Q4.3.7: Assume that a new vehicle you want to buy has two engine options that are equally clean, dependable, powerful, odorless, and smooth running. One uses gasoline and the other uses diesel fuel and gets $40 \%$ more miles per gallon but costs $\$ 2,000$ more. Which engine option would you buy?

Table 4.3.7. Purchase Preference Between Diesel and Gasoline Vehicles by Vehicle Type (2001 and 2005)

\begin{tabular}{|c|c|c|c|c|c|c|c|c|c|c|c|c|}
\hline \multirow{3}{*}{$\begin{array}{l}\text { Vehicle } \\
\text { Engine } \\
\text { Option }\end{array}$} & & & \multicolumn{10}{|c|}{ Vehicle Type } \\
\hline & \multicolumn{2}{|c|}{ Total } & Smal & Car & \multicolumn{2}{|c|}{$\begin{array}{l}\text { Large } \\
\text { Car }\end{array}$} & \multicolumn{2}{|c|}{ Minivan } & \multicolumn{2}{|c|}{ SUV } & \multicolumn{2}{|c|}{$\begin{array}{c}\text { Pickup/ } \\
\text { Van }\end{array}$} \\
\hline & '01 & 65 & '01 & 65 & '01 & 65 & '01 & 65 & '01 & 65 & '01 & 65 \\
\hline Gasoline & 71 & 40 & 75 & 40 & 81 & 40 & 71 & 28 & 62 & 52 & 65 & 30 \\
\hline Diesel & 27 & 52 & 21 & 55 & 18 & 56 & 27 & 65 & 37 & 44 & 34 & 69 \\
\hline Don't know & 2 & 8 & 4 & 5 & 4 & 4 & 2 & 7 & 1 & 4 & 1 & 1 \\
\hline
\end{tabular}

Source: For 2001: ORC for NREL (2001c), Study No. 710288, N=989; For 2005: ORC for NREL (2005b), Study No. 714388, N=1,042 
If did not choose diesel, ask:

Q4.3.8: Why did you reject the diesel option? (unaided question)

Table 4.3.8. Reasons for Rejecting a Diesel Option (2001 and 2005)

\begin{tabular}{|c|c|c|}
\hline Reasons & $\begin{array}{c}2001 \\
(\%)\end{array}$ & $\begin{array}{c}\text { Sept. } 2005 \\
(\%)\end{array}$ \\
\hline $\begin{array}{l}\text { Environmental (pollutes the air, odor/smell/stink, too much noise, } \\
\text { other related mentions) }\end{array}$ & 39 & 12 \\
\hline Cost (expense, initial cost $/ \$ 2,000$ more, other related mentions ) & 19 & 30 \\
\hline Lack of fuel availability & 17 & 10 \\
\hline Don't know enough/know nothing about it/never owned one & 11 & 5 \\
\hline Engine problems (difficult to start in winter, other related mentions) & 8 & * \\
\hline Just don't like diesel/husband doesn't like diesel & 7 & $*$ \\
\hline Prefer/used to/satisfied with gasoline & 5 & * \\
\hline Other & 4 & 9 \\
\hline Don't know & 4 & * \\
\hline
\end{tabular}

Source: For 2001: ORC for NREL (2001c), Study No. 710288, N=723. For 2005: ORC for NREL (2005b), Study No. 714388, N=1,042

Note: Percentages do not total 100 , because each respondent could volunteer more than one response.

Reasons for Rejecting the Diesel Option (723 respondents in 2001 and 381 respondents in 2005)

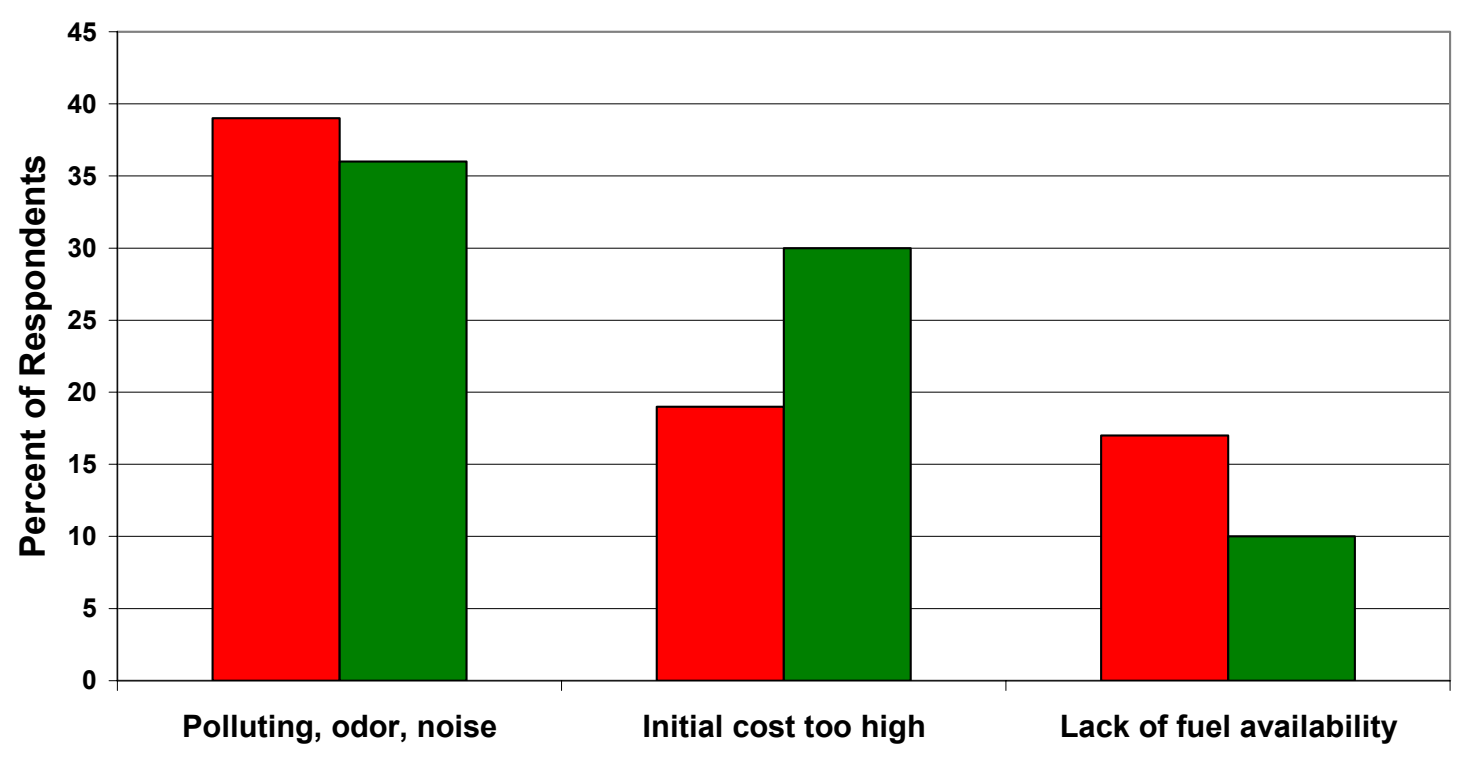

$\square 2001 \square 2005$ 
If chose diesel, ask:

Q4.3.9: Why did you choose the diesel option? (unaided question)

Table 4.3.9. Reasons for Choosing a Diesel Option (2001 and 2005)

\begin{tabular}{|l|r|r|}
\hline Reasons & 2001 (\%) & Sept. 2005 (\%) \\
\hline $\begin{array}{l}\text { Fuel economy (better gas mileage/fuel economy, 40\% } \\
\text { better mileage/miles per gallon) }\end{array}$ & 46 & 42 \\
\hline $\begin{array}{l}\text { Cost (saves money/pays for itself over time, cheaper than } \\
\text { gasoline, economical) }\end{array}$ & 34 & 41 \\
\hline Dependability (diesel engine lasts longer, more reliable) & 12 & 9 \\
\hline Environmental (burns cleaner, other related mentions) & 10 & 3 \\
\hline I have/drive vehicle with diesel engine & 4 & 3 \\
\hline More power/horsepower & 3 & 9 \\
\hline Other /don't know & 10 & 7 \\
\hline
\end{tabular}

Source: For 2001: ORC for NREL (2001c), Study No. 710288, N=266. For 2005: ORC for NREL (2005b), Study No. 714388, N=1,042

Note: Percentages do not total 100, because each respondent could volunteer more than one response. 


\section{General Preferences}

Q4.3.10: Which one of the following are you planning to purchase for your next household vehicle?

Table 4.3.10. Vehicle-Purchase Preferences (2004 and 2005)

\begin{tabular}{|c|c|c|c|}
\hline Type of Vehicle & 2004 & $\begin{array}{l}\text { May } \\
2005\end{array}$ & $\begin{array}{c}\text { September } \\
2005\end{array}$ \\
\hline $\begin{array}{l}\text { Large car, same size or larger than a Honda } \\
\text { Accord, Chevy Malibu, or Toyota Camry }\end{array}$ & 28 & 25 & 22 \\
\hline SUV or sport utility vehicle & 23 & 17 & 17 \\
\hline $\begin{array}{l}\text { Small car, smaller than a Honda Accord, Chevy } \\
\text { Malibu, or Toyota Camry }\end{array}$ & 20 & 24 & 33 \\
\hline Pickup truck or large van & 18 & 15 & 14 \\
\hline Minivan & 6 & 9 & 9 \\
\hline Other/ don't know & 4 & 9 & 4 \\
\hline Do not plan to purchase new household vehicle & $\mathrm{N} / \mathrm{A}$ & $\mathrm{N} / \mathrm{A}$ & $* *$ \\
\hline Total & 99 & 99 & 99 \\
\hline
\end{tabular}

Source: ORC for NREL (2004a), Study No. 713218, N=1,000. For May 2005: ORC for NREL (2005a), $\mathrm{N}=1,012$. For September 2005: ORC for NREL (2005b), Study No. 714388, N=1,042

** Because "don't plan to purchase new household vehicle" was not an optional response during the first two surveys, we have normalized the September 2005 results to reflect that difference.

Q4.3.11: When you purchase your next household vehicle, how likely are you to buy each of the following?

Would you say you definitely will buy it, you would be very likely to buy it, you would be likely to buy it, you would be not likely to buy it or you definitely won't buy it?

Table 4.3.11. Vehicle-Purchase Preferences - Hybrid-electric vs. Diesel (2004)

\begin{tabular}{|l|r|r|}
\hline \multirow{2}{*}{ Type of Vehicle } & \multicolumn{2}{|c|}{ Percent } \\
\cline { 2 - 3 } & $\begin{array}{c}\text { Hybrid- } \\
\text { electric }\end{array}$ & Diesel \\
\hline Definitely will buy & 7 & 4 \\
\hline Very likely to buy & 8 & 4 \\
\hline Likely to buy & 27 & 14 \\
\hline Not likely to buy & 31 & 36 \\
\hline Definitely won't buy & 20 & 38 \\
\hline Don't know & 6 & 3 \\
\hline Total & 99 & 99 \\
\hline
\end{tabular}

Source: ORC for NREL (2004a), Study No. 713218, N=1,000 
Q4.3.12: Suppose you were given an extra $\$ 1,000$ that you must spend on acceleration, fuel economy and/or the ability to tow, when buying your next vehicle. How much would you spend on each attribute? You can spend all the money on one attribute or split it among two or three attributes.

Table 4.3.12. Priority on Vehicle Attributes (2004)

\begin{tabular}{|l|r|}
\hline Attribute & Dollars \\
\hline Fuel economy & $\$ 609$ \\
\hline Acceleration & $\$ 248$ \\
\hline Ability to tow & $\$ 143$ \\
\hline Total & $\$ 1,000$ \\
\hline
\end{tabular}

Source: ORC for NREL (2004a), Study No. 713218, N=1,000

Q4.3.13: Which one of the following are you planning to purchase for your next household vehicle?

Table 4.3.13. Vehicle-Purchase Preferences (May 2005)

\begin{tabular}{|l|r|}
\hline Type of Vehicle & Percent \\
\hline A new vehicle in fewer than 3 years & 24 \\
\hline A new vehicle in 3 to 6 years & 20 \\
\hline A new vehicle in 7 or more years & 7 \\
\hline A used vehicle in fewer than 3 years & 18 \\
\hline A used vehicle in 3 to 6 years & 14 \\
\hline A used vehicle in 7 or more years & 4 \\
\hline Don't drive & 3 \\
\hline Don't know/do not plan to purchase household & 9 \\
\hline vehicle & 99 \\
\hline Total & \\
\hline
\end{tabular}

Source: ORC for NREL (2005a), N =1,012. 


\section{Appendix A}

ORC STUDY \#714388, VEHICLE FUEL EFFICIENCY

SEPTEMBER 22, 2005 
TABLE 2.2 .3 (A)

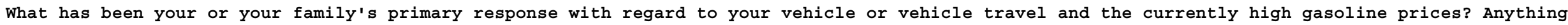
else? - Unaided

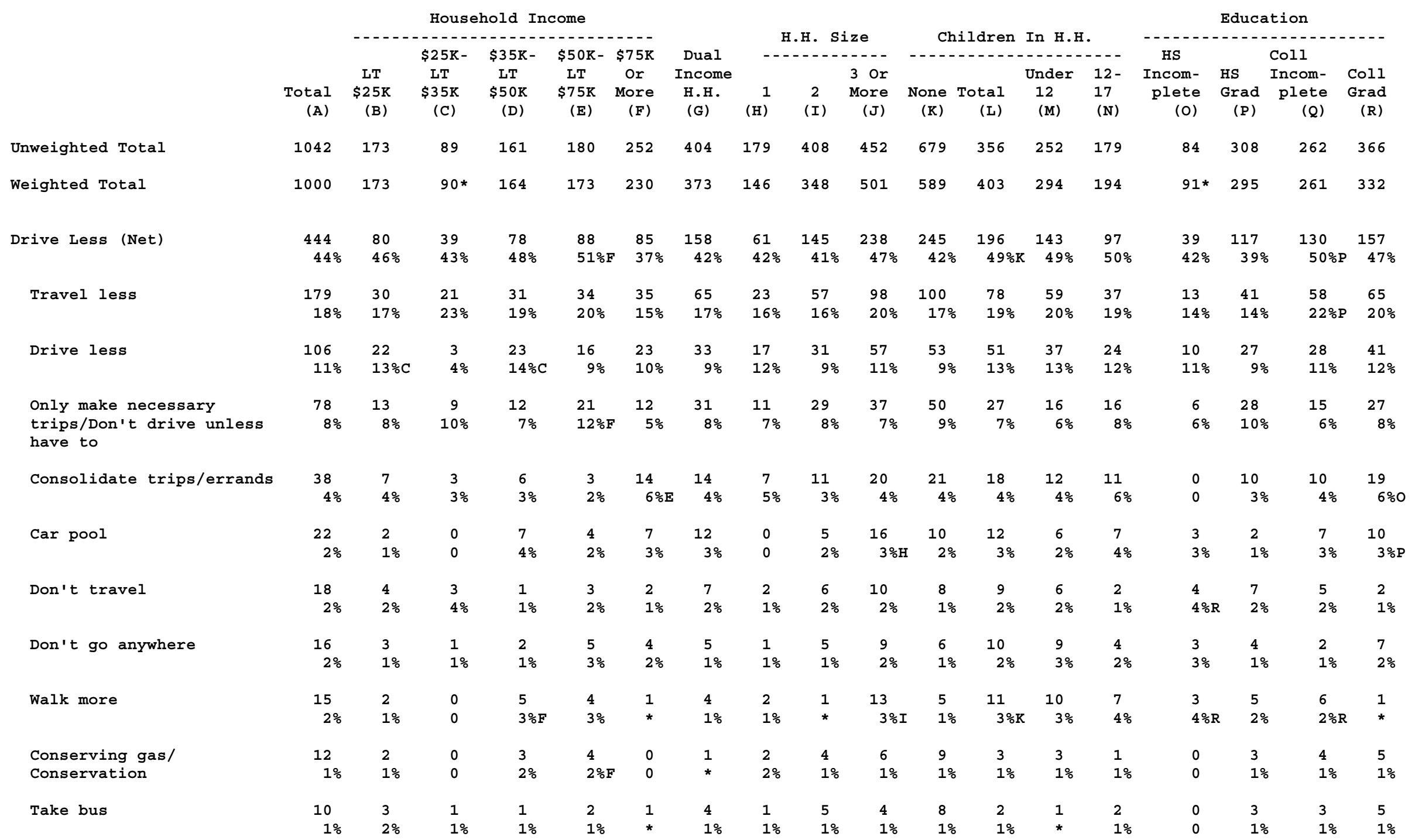

Proportions/Means: Columns Tested (5\% risk level) - B/C/D/E/F - H/I/J - K/L - O/P/Q/R

overlap formulae used. * small base 
TABLE 2.2 .3 (B)

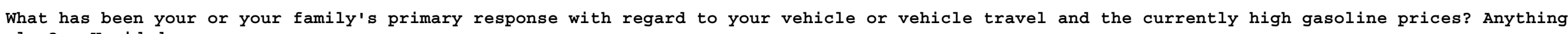
else? - Unaided

\begin{tabular}{|c|c|c|c|c|c|c|c|c|c|c|c|c|c|c|c|c|c|c|}
\hline & & --- & Househ & old Inc & ome &.- & & & H. Siz & $\mathrm{ze}$ & Chil & ildren & In $\mathrm{H} . \mathrm{H}$ & & & Educati & ion & \\
\hline & & & $\$ 25 \mathrm{~K}-$ & $\$ 35 \mathrm{~K}-$ & $\$ 50 \mathrm{~K}-\$ 7$ & $75 \mathrm{~K}$ & Dual & $-\ldots$ & $\ldots$ & $-\ldots$ & -----1 & $-1-1$ & $-\ldots$ & - & HS & & 011 & \\
\hline & & LT & LT & LT & LT $\quad 0$ & or In & ncome & & & 3 or & & & Under & $12-$ & Incom- $\mathrm{F}$ & HS & ncom- & Coll \\
\hline & $\begin{array}{r}\text { Total } \\
\text { (A) }\end{array}$ & $\begin{array}{l}\$ 25 \mathrm{~K} \\
(B)\end{array}$ & $\begin{array}{l}\$ 35 \mathrm{~K} \\
(\mathrm{C})\end{array}$ & $\begin{array}{l}\$ 50 \mathrm{~K} \\
\text { (D) }\end{array}$ & $\begin{array}{l}\$ 75 \mathrm{~K} \\
(\mathrm{E})\end{array}$ & $\begin{array}{l}\text { More } \\
(\mathrm{F})\end{array}$ & $\begin{array}{l}\text { H.H. } \\
\text { (G) }\end{array}$ & $\begin{array}{r}1 \\
(\mathrm{H})\end{array}$ & $\begin{array}{cc}2 & M \\
(I) & \end{array}$ & $\begin{array}{l}\text { More } \\
(\mathrm{J})\end{array}$ & $\begin{array}{l}\text { None } T o \\
(\mathrm{~K})\end{array}$ & $\begin{array}{c}\text { Total } \\
\text { (L) }\end{array}$ & $\begin{array}{l}12 \\
(\mathrm{M})\end{array}$ & $\begin{array}{l}17 \\
(\mathrm{~N})\end{array}$ & $\begin{array}{c}\text { plete } \\
(0)\end{array}$ & $\underset{(P)}{\text { Grad }} \quad \mathrm{p}$ & $\begin{array}{l}\text { plete } \\
\text { (Q) }\end{array}$ & $\begin{array}{l}\text { Grad } \\
\quad(R)\end{array}$ \\
\hline Weighted Total & 1000 & 173 & $90 *$ & 164 & 173 & 230 & 373 & 146 & 348 & 501 & 589 & 403 & 294 & 194 & $91 *$ & 295 & 261 & 332 \\
\hline Ride bike more & 7 & 1 & 1 & 1 & 4 & 0 & 4 & 3 & 0 & 4 & 3 & 4 & 4 & 3 & 1 & 1 & 4 & 2 \\
\hline & $1 \%$ & * & $2 \%$ & $1 \%$ & $3 \% \mathrm{~F}$ & 0 & $1 \%$ & $2 \% I$ & 0 & $1 \%$ & $1 \%$ & $1 \%$ & $1 \%$ & $2 \%$ & $1 \%$ & * & $2 \%$ & $1 \%$ \\
\hline All other drive less & 16 & 4 & 1 & 1 & 4 & 3 & 6 & 5 & 6 & 5 & 12 & 4 & 4 & 2 & 2 & 3 & 6 & 5 \\
\hline mentions & $2 \%$ & $2 \%$ & $2 \%$ & * & $2 \%$ & $1 \%$ & $2 \%$ & $4 \% \mathrm{~J}$ & $2 \%$ & $1 \%$ & $2 \%$ & $1 \%$ & $1 \%$ & $1 \%$ & $3 \%$ & $1 \%$ & $2 \%$ & $1 \%$ \\
\hline No effect/No change/Travel & 158 & 20 & 14 & 20 & 22 & 56 & 63 & 27 & 67 & 64 & 108 & 50 & 29 & 27 & 11 & 40 & 36 & 67 \\
\hline as often & $16 \%$ & $11 \%$ & $16 \%$ & $12 \%$ & $13 \%$ & $\begin{array}{l}25 \% \mathrm{BD} \\
\mathrm{E}\end{array}$ & $17 \%$ & $19 \%$ & $19 \% \mathrm{~J}$ & $13 \%$ & $18 \% \mathrm{~L}$ & $12 \%$ & $10 \%$ & $14 \%$ & $12 \%$ & $13 \%$ & $14 \%$ & $20 \% P$ \\
\hline Gas prices are ridiculous/ & 125 & 32 & 10 & 21 & 18 & 26 & 49 & 19 & 35 & 72 & 68 & 58 & 52 & 23 & 18 & 49 & 29 & 24 \\
\hline outrageous/too high & $13 \%$ & $19 \% E$ & $11 \%$ & $13 \%$ & $10 \%$ & $11 \%$ & $13 \%$ & $13 \%$ & $10 \%$ & $14 \%$ & $12 \%$ & $14 \%$ & $18 \%$ & $12 \%$ & $19 \% R$ & $17 \% \mathrm{R}$ & $11 \%$ & $7 \%$ \\
\hline Don't like it/Unhappy/Angry & 77 & 12 & 7 & 17 & 10 & 18 & 32 & 10 & 31 & 36 & 44 & 33 & 21 & 17 & 11 & 23 & 21 & 21 \\
\hline & $8 \%$ & $7 \%$ & $8 \%$ & $11 \%$ & $6 \%$ & $8 \%$ & $8 \%$ & $7 \%$ & $9 \%$ & $7 \%$ & $7 \%$ & $8 \%$ & $7 \%$ & $9 \%$ & $12 \%$ & $8 \%$ & $8 \%$ & $6 \%$ \\
\hline Just pay the price/Using & 53 & 0 & 7 & 12 & 12 & 13 & 21 & 4 & 20 & 29 & 32 & 21 & 15 & 11 & 3 & 19 & 13 & 17 \\
\hline gas/driving is a necessity & $5 \%$ & 0 & $8 \% B$ & $7 \% B$ & $7 \% B$ & $6 \% \mathrm{~B}$ & $6 \%$ & $3 \%$ & $6 \%$ & $6 \%$ & $5 \%$ & $5 \%$ & $5 \%$ & $6 \%$ & $3 \%$ & $6 \%$ & $5 \%$ & $5 \%$ \\
\hline Use most fuel-efficient & 25 & 0 & 2 & 1 & 8 & 10 & 11 & 1 & 8 & 17 & 13 & 12 & 7 & 7 & 0 & 6 & 10 & 9 \\
\hline vehicle I own & $3 \%$ & 0 & $3 \%$ & $1 \%$ & $5 \% \mathrm{BD}$ & $4 \% \mathrm{BD}$ & $3 \%$ & $1 \%$ & $2 \%$ & $3 \%$ & $2 \%$ & $3 \%$ & $2 \%$ & $4 \%$ & 0 & $2 \%$ & $4 \%$ & $3 \%$ \\
\hline Gas prices are result of & 22 & 2 & 2 & 5 & 3 & 6 & 11 & 3 & 9 & 10 & 17 & 6 & 4 & 4 & 1 & 9 & 4 & 8 \\
\hline $\begin{array}{l}\text { price gouging/corruption, } \\
\text { etc. }\end{array}$ & $2 \%$ & $1 \%$ & $2 \%$ & $3 \%$ & $2 \%$ & $3 \%$ & $3 \%$ & $2 \%$ & $3 \%$ & $2 \%$ & $3 \%$ & $1 \%$ & $1 \%$ & $2 \%$ & $1 \%$ & $3 \%$ & $2 \%$ & $3 \%$ \\
\hline Changed Vehicle (Net) & 22 & 3 & 1 & 2 & 7 & 3 & 10 & 2 & 10 & 9 & 12 & 9 & 6 & 6 & 0 & 4 & 3 & 14 \\
\hline & $2 \%$ & $2 \%$ & $1 \%$ & $1 \%$ & $4 \%$ & $1 \%$ & $3 \%$ & $1 \%$ & $3 \%$ & $2 \%$ & $2 \%$ & $2 \%$ & $2 \%$ & $3 \%$ & 0 & $1 \%$ & $1 \%$ & $4 \% \mathrm{PQ}$ \\
\hline Bought more fuel- & 11 & 1 & 1 & 2 & 3 & 1 & 5 & 1 & 8 & 3 & 8 & 3 & 2 & 3 & 0 & 2 & 2 & 6 \\
\hline efficient vehicle & $1 \%$ & $1 \%$ & $1 \%$ & $1 \%$ & $2 \%$ & * & $1 \%$ & $1 \%$ & $2 \% J$ & $1 \%$ & $1 \%$ & $1 \%$ & $1 \%$ & $1 \%$ & 0 & $1 \%$ & $1 \%$ & $2 \%$ \\
\hline Sold/Traded in vehicle & 4 & 0 & 0 & 1 & 2 & 1 & 2 & 1 & 1 & 3 & 2 & 3 & 2 & 2 & 0 & 1 & 1 & 3 \\
\hline & * & 0 & 0 & $1 \%$ & $1 \%$ & $1 \%$ & $1 \%$ & $1 \%$ & * & $1 \%$ & * & $1 \%$ & $1 \%$ & $1 \%$ & 0 & * & * & $1 \%$ \\
\hline All other changed vehicle & 8 & 2 & 0 & 0 & 3 & 2 & 4 & 1 & 3 & 4 & 4 & 4 & 2 & 2 & 0 & 1 & 1 & 6 \\
\hline mentions & $1 \%$ & $1 \%$ & 0 & 0 & $2 \%$ & $1 \%$ & $1 \%$ & $1 \%$ & $1 \%$ & $1 \%$ & $1 \%$ & $1 \%$ & $1 \%$ & $1 \%$ & 0 & * & $1 \%$ & $2 \%$ \\
\hline
\end{tabular}

Proportions/Means: Columns Tested (5\% risk level) - B/C/D/E/F - H/I/J - K/L - O/P/Q/R

Overlap formulae used. * small base 
TABLE 2.2 .3 (C)

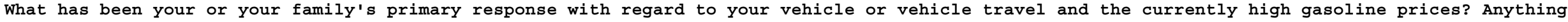
else? - Unaided

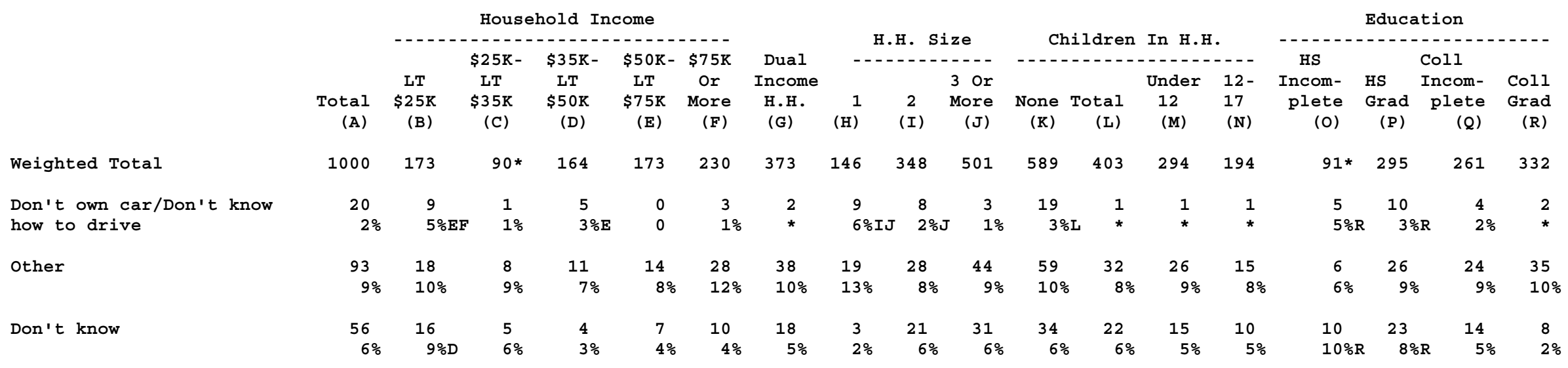

Proportions/Means: Columns Tested (5\% risk level) - B/C/D/E/F - H/I/J - K/L - O/P/Q/R

Overlap formulae used. * small base 
TABLE 2.2 .4

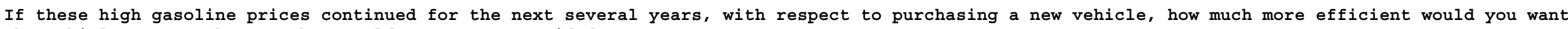
the vehicle you purchase to be? Would you say... - Aided

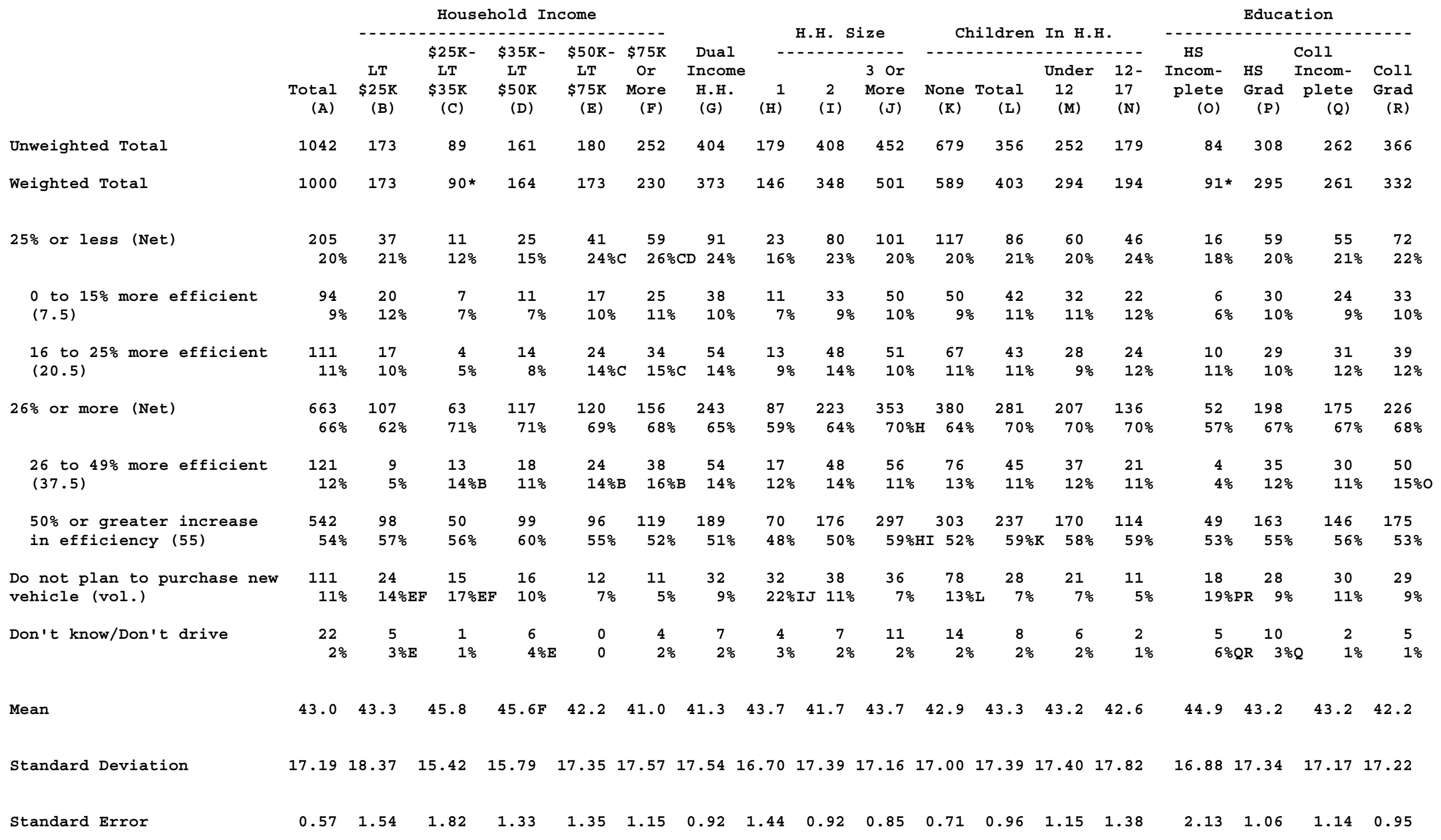


TABLE 2.2 .5 (A)

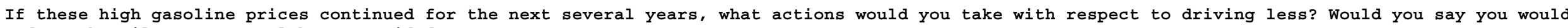
reduce the miles you travel by... - Aided

\begin{tabular}{|c|c|c|c|c|c|c|c|c|c|c|c|c|c|c|c|c|c|c|}
\hline & & - & Househ & hold Inc & come &.-- & & & .H. Si & ize & Chi] & ildren & In $\mathrm{H} . \mathrm{H}$ & & $\begin{array}{r}E \\
-\end{array}$ & Educat: & tion & - \\
\hline & & & $\$ 25 \mathrm{~K}-$ & $\$ 35 \mathrm{~K}-$ & $\$ 50 \mathrm{~K}-$ & $\$ 75 \mathrm{~K}$ & Dual & $-\ldots$ &..-- & ---- & ----- & (n- & $-\ldots$ & $-\ldots$ & HS & & Coll & \\
\hline & & LT & LT & LT & LT & or & Income & & & 3 or & & & Under & $12-$ & Incom- & HS & Incom- & Coll \\
\hline & $\begin{array}{r}\text { Total } \\
\text { (A) }\end{array}$ & $\begin{array}{r}\$ 25 \mathrm{~K} \\
(\mathrm{~B})\end{array}$ & $\begin{array}{r}\$ 35 \mathrm{~K} \\
(\mathrm{C})\end{array}$ & $\begin{array}{l}\$ 50 \mathrm{~K} \\
\text { (D) }\end{array}$ & $\begin{array}{c}\$ 75 \mathrm{~K} \\
(\mathrm{E})\end{array}$ & $\begin{array}{r}\text { More } \\
(\mathrm{F})\end{array}$ & $\begin{array}{l}\text { Н.н. } \\
(\mathrm{G})\end{array}$ & $\begin{array}{r}1 \\
(\mathrm{H})\end{array}$ & $\begin{array}{c}2 \\
(I)\end{array}$ & $\begin{array}{c}\text { More } \\
(\mathrm{J})\end{array}$ & $\begin{array}{l}\text { None } T c \\
(\mathrm{~K})\end{array}$ & $\begin{array}{c}\text { rotal } \\
\text { (L) }\end{array}$ & $\begin{array}{l}12 \\
(\mathrm{M})\end{array}$ & $\begin{array}{l}17 \\
(\mathrm{~N})\end{array}$ & $\begin{array}{c}\text { plete } \\
(0)\end{array}$ & $\begin{array}{c}\text { Grad } \\
\text { (P) }\end{array}$ & $\begin{array}{c}\text { plete } \\
(Q)\end{array}$ & $\begin{array}{l}\text { Grad } \\
\text { (R) }\end{array}$ \\
\hline Unweighted Total & 1042 & 173 & 89 & 161 & 180 & 252 & 404 & 179 & 408 & 452 & 679 & 356 & 252 & 179 & 84 & 308 & 262 & 366 \\
\hline Weighted Total & 1000 & 173 & $90 *$ & 164 & 173 & 230 & 373 & 146 & 348 & 501 & 589 & 403 & 294 & 194 & 91* & 295 & 261 & 332 \\
\hline Any (Net) & $\begin{array}{l}829 \\
83 \%\end{array}$ & $\begin{array}{r}142 \\
82 \%\end{array}$ & $\begin{array}{l}75 \\
84 \%\end{array}$ & $\begin{array}{l}145 \\
88 \%\end{array}$ & $\begin{array}{l}147 \\
85 \%\end{array}$ & $\begin{array}{l}197 \\
86 \%\end{array}$ & $\begin{array}{l}318 \\
85 \%\end{array}$ & $\begin{array}{l}112 \\
76 \%\end{array}$ & $\begin{array}{l}291 \\
83 \%\end{array}$ & $\begin{array}{l}425 \\
85 \% \mathrm{H}\end{array}$ & $\begin{array}{l}478 \\
\quad 81 \%\end{array}$ & $\begin{array}{l}346 \\
86 \%\end{array}$ & $\begin{array}{l}246 \\
84 \%\end{array}$ & $\begin{array}{l}175 \\
90 \%\end{array}$ & $\begin{array}{l}65 \\
72 \%\end{array}$ & $\begin{array}{l}249 \\
85 \% 0\end{array}$ & $\begin{array}{l}220 \\
84 \% 0\end{array}$ & $\begin{array}{l}284 \\
\quad 86 \% 0\end{array}$ \\
\hline $25 \%$ or less (Subnet) & 514 & 56 & 45 & 85 & 102 & 140 & 215 & 75 & 185 & 254 & 301 & 212 & 153 & 108 & 37 & 140 & 127 & 202 \\
\hline & $51 \%$ & $32 \%$ & $50 \% B$ & $52 \% B$ & $59 \% B$ & $361 \% \mathrm{~B}$ & $58 \%$ & $51 \%$ & $53 \%$ & $51 \%$ & $51 \%$ & $53 \%$ & $52 \%$ & $55 \%$ & $40 \%$ & $48 \%$ & $49 \%$ & $61 \% \mathrm{OPQ}$ \\
\hline Less than $5 \%(4)$ & 162 & 19 & 16 & 30 & 31 & 46 & 71 & 23 & 45 & 94 & 74 & 88 & 59 & 38 & 14 & 43 & 43 & 60 \\
\hline & $16 \%$ & $11 \%$ & $18 \%$ & $18 \%$ & $18 \%$ & $20 \% B$ & $19 \%$ & $16 \%$ & $13 \%$ & $19 \% I$ & I $\quad 13 \%$ & $22 \% K$ & $20 \%$ & $20 \%$ & $15 \%$ & $15 \%$ & $17 \%$ & $18 \%$ \\
\hline 5 to $15 \%(10)$ & 160 & 20 & 15 & 27 & 32 & 41 & 57 & 28 & 64 & 68 & 109 & 52 & 43 & 29 & 9 & 51 & 39 & 59 \\
\hline & $16 \%$ & $11 \%$ & $16 \%$ & $16 \%$ & $19 \%$ & $18 \%$ & $15 \%$ & $19 \%$ & $18 \%$ & $14 \%$ & $18 \% \mathrm{~L}$ & $13 \%$ & $15 \%$ & $15 \%$ & $10 \%$ & $17 \%$ & $15 \%$ & $18 \%$ \\
\hline 16 to $25 \%(20.5)$ & 191 & 18 & 15 & 28 & 39 & 53 & 87 & 24 & 76 & 91 & 119 & 72 & 51 & 40 & 14 & 47 & 45 & 83 \\
\hline & $19 \%$ & $10 \%$ & $16 \%$ & $17 \%$ & $23 \% \mathrm{~B}$ & $323 \% B$ & $23 \%$ & $16 \%$ & $22 \%$ & $18 \%$ & $20 \%$ & $18 \%$ & $17 \%$ & $21 \%$ & $16 \%$ & $16 \%$ & $17 \%$ & $25 \% \mathrm{PQ}$ \\
\hline $26 \%$ or more (Subnet) & 315 & 86 & 30 & 59 & 44 & 58 & 103 & 37 & 106 & 171 & 177 & 134 & 93 & 67 & 28 & 109 & 93 & 82 \\
\hline & $31 \%$ & $\begin{array}{l}50 \% \mathrm{CDE} \\
\mathrm{F}\end{array}$ & E $34 \%$ & $36 \% \mathrm{~F}$ & $25 \%$ & $25 \%$ & $28 \%$ & $25 \%$ & $30 \%$ & $34 \% \mathrm{H}$ & $30 \%$ & $33 \%$ & $32 \%$ & $34 \%$ & $31 \%$ & $37 \% R$ & $36 \% R$ & $25 \%$ \\
\hline 26 to $49 \%(37.5)$ & 88 & 17 & 4 & 18 & 13 & 23 & 32 & 7 & 29 & 52 & 47 & 41 & 29 & 18 & 4 & 25 & 31 & 28 \\
\hline & $9 \%$ & $10 \%$ & $5 \%$ & $11 \%$ & $7 \%$ & $10 \%$ & $9 \%$ & $5 \%$ & $8 \%$ & $10 \% \mathrm{H}$ & $8 \%$ & $10 \%$ & $10 \%$ & $9 \%$ & $4 \%$ & $8 \%$ & $12 \%$ & $8 \%$ \\
\hline $50 \%$ or more (55) & 227 & 69 & 26 & 41 & 31 & 35 & 71 & 30 & 77 & 119 & 130 & 93 & 63 & 49 & 25 & 84 & 62 & 54 \\
\hline & $23 \%$ & $40 \% \mathrm{DEF}$ & F $29 \% F$ & $25 \% F$ & $18 \%$ & $15 \%$ & $19 \%$ & $20 \%$ & $22 \%$ & $24 \%$ & $22 \%$ & $23 \%$ & $22 \%$ & $25 \%$ & $27 \% R$ & $29 \% R$ & $24 \% R$ & $16 \%$ \\
\hline None $(0)$ & 121 & 21 & 10 & 12 & 19 & 30 & 46 & 20 & 44 & 56 & 77 & 43 & 40 & 13 & 10 & 31 & 35 & 39 \\
\hline & $12 \%$ & $12 \%$ & $11 \%$ & $7 \%$ & $11 \%$ & $13 \%$ & $12 \%$ & $14 \%$ & $13 \%$ & $11 \%$ & $13 \%$ & $11 \%$ & $14 \%$ & $7 \%$ & $11 \%$ & $11 \%$ & $13 \%$ & $12 \%$ \\
\hline Don't know/Don't drive & 50 & 11 & 5 & 8 & 8 & 3 & 9 & 14 & 14 & 19 & 33 & 14 & 9 & 7 & 16 & 14 & 6 & 9 \\
\hline & $5 \%$ & $6 \% \mathrm{~F}$ & $5 \%$ & $5 \% F$ & $4 \%$ & $1 \%$ & $2 \%$ & $10 \% I J$ & J $\quad 4 \%$ & $4 \%$ & $6 \%$ & $3 \%$ & $3 \%$ & $4 \%$ & $17 \% \mathrm{PQ}$ & QR $5 \%$ & $2 \%$ & $3 \%$ \\
\hline Mean (Including None) & 23.1 & $\begin{array}{l}31.1 \mathrm{DE} 2 \\
\mathrm{~F}\end{array}$ & 24.6 & $25.1 \mathrm{~F}$ & 20.9 & 19.6 & 21.3 & 20.8 & 23.0 & 23.8 & 22.9 & 23.1 & 22.1 & 24.7 & 25.6 & $25.7 \mathrm{R}$ & 23.8 & 20.3 \\
\hline
\end{tabular}


TABLE 2.2.5 (B)

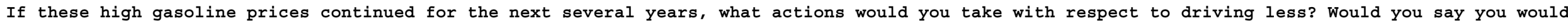
reduce the miles you travel by... - Aided

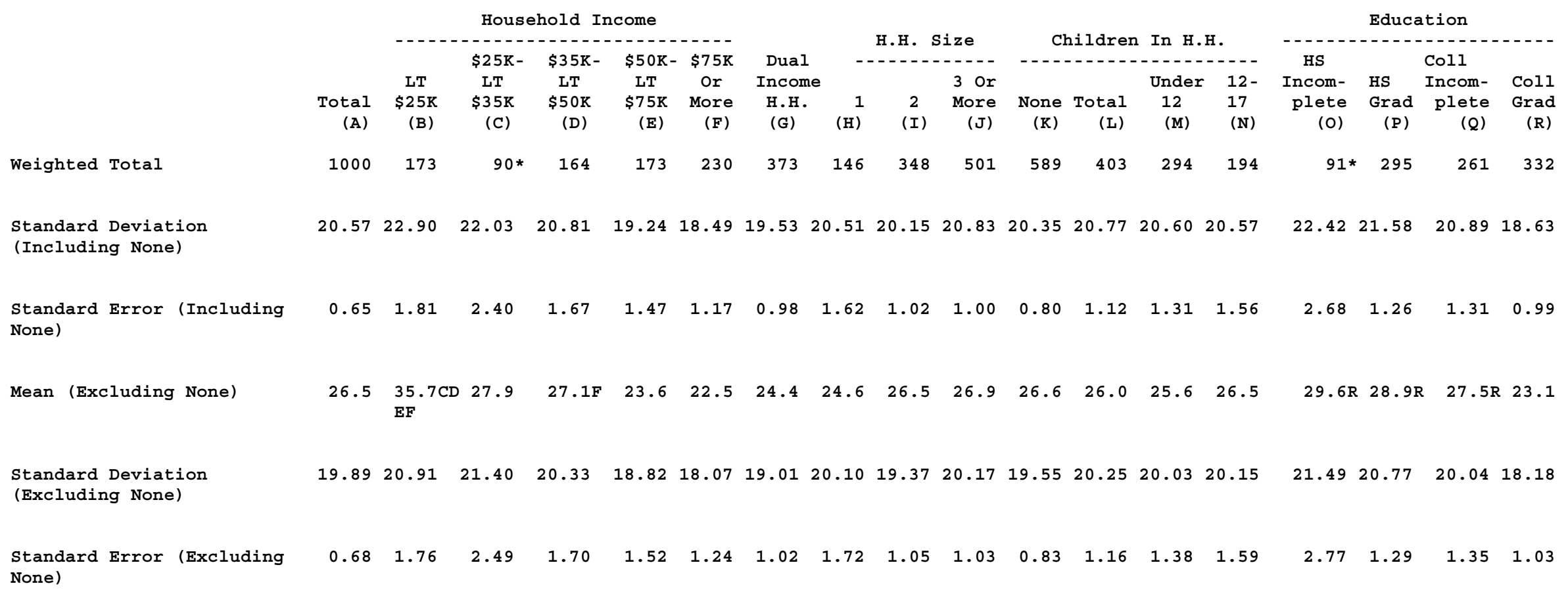

Proportions/Means: Columns Tested (5\% risk level) - B/C/D/E/F - H/I/J - K/L - O/P/Q/R

overlap formulae used. * small base 


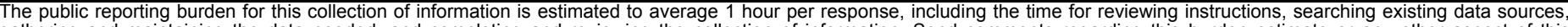

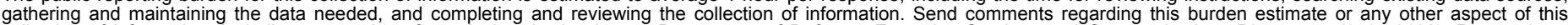

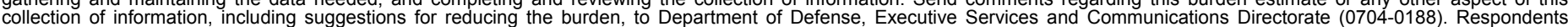

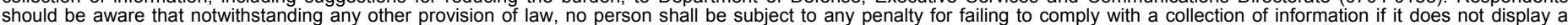

currently valid OMB control number.

PLEASE DO NOT RETURN YOUR FORM TO THE ABOVE ORGANIZATION.

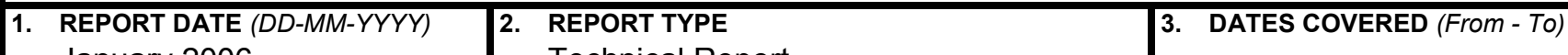
January 2006

Technical Report

4. TITLE AND SUBTITLE

Consumer Views on Transportation and Energy (Third Edition) 5a. CONTRACT NUMBER

DE-AC36-99-GO10337

5b. GRANT NUMBER

5c. PROGRAM ELEMENT NUMBER

5d. PROJECT NUMBER

NREL/TP-620-39047

5e. TASK NUMBER

ASA5.1315

5f. WORK UNIT NUMBER
7. PERFORMING ORGANIZATION NAME(S) AND ADDRESS(ES)

National Renewable Energy Laboratory

1617 Cole Blvd.

Golden, CO 80401-3393
8. PERFORMING ORGANIZATION REPORT NUMBER

NREL/TP-620-39047

9. SPONSORING/MONITORING AGENCY NAME(S) AND ADDRESS(ES)

10. SPONSOR/MONITOR'S ACRONYM(S) NREL

11. SPONSORING/MONITORING AGENCY REPORT NUMBER

12. DISTRIBUTION AVAILABILITY STATEMENT

National Technical Information Service

U.S. Department of Commerce

5285 Port Royal Road

Springfield, VA 22161

13. SUPPLEMENTARY NOTES

14. ABSTRACT (Maximum 200 Words)

This report has been assembled to provide the U.S. Department of Energy's (DOE's) Office of Energy Efficiency and Renewable Energy (EERE) with an idea of how the American public views various transportation, energy, and environmental issues. The data presented in this report have been drawn from multiple sources: surveys conducted by the Opinion Research Corporation (ORC) for the National Renewable Energy Laboratory (NREL) that are commissioned and funded by EERE, Gallup polls, news organization polls, surveys conducted by independent groups and academic institutions, and other sources.

\section{SUBJECT TERMS}

analysis; transportation; consumers; energy; oil; gasoline; fuel; foreign oil dependence; sport utility vehicles; SUVs; fuel-efficiency vehicles; ethanol; hybrid-electric vehicles; advanced-technology vehicles; diesel; gas prices; greenhouse gas emissions; environment; Michelle Kubik; Transportation Energy Survey Data Book

\begin{tabular}{|c|c|c|c|c|}
\hline \multicolumn{3}{|c|}{ 16. SECURITY CLASSIFICATION OF: } & \multirow{2}{*}{$\begin{array}{l}\text { 17. LIMITATION } \\
\text { OF ABSTRACT } \\
\text { UL }\end{array}$} & \multirow{2}{*}{$\begin{array}{l}\text { 18. NUMBER } \\
\text { OF PAGES }\end{array}$} \\
\hline $\begin{array}{l}\text { a. REPORT } \\
\text { Unclassified }\end{array}$ & $\begin{array}{l}\text { b. ABSTRACT } \\
\text { Unclassified }\end{array}$ & $\begin{array}{l}\text { c. THIS PAGE } \\
\text { Unclassified }\end{array}$ & & \\
\hline
\end{tabular}

19b. TELEPHONE NUMBER (Include area code) 